\title{
Hydrology and Water Quality in the Nederlo Creek Basin, Wisconsin, Before Construction of Two Water-Retention Structures
}

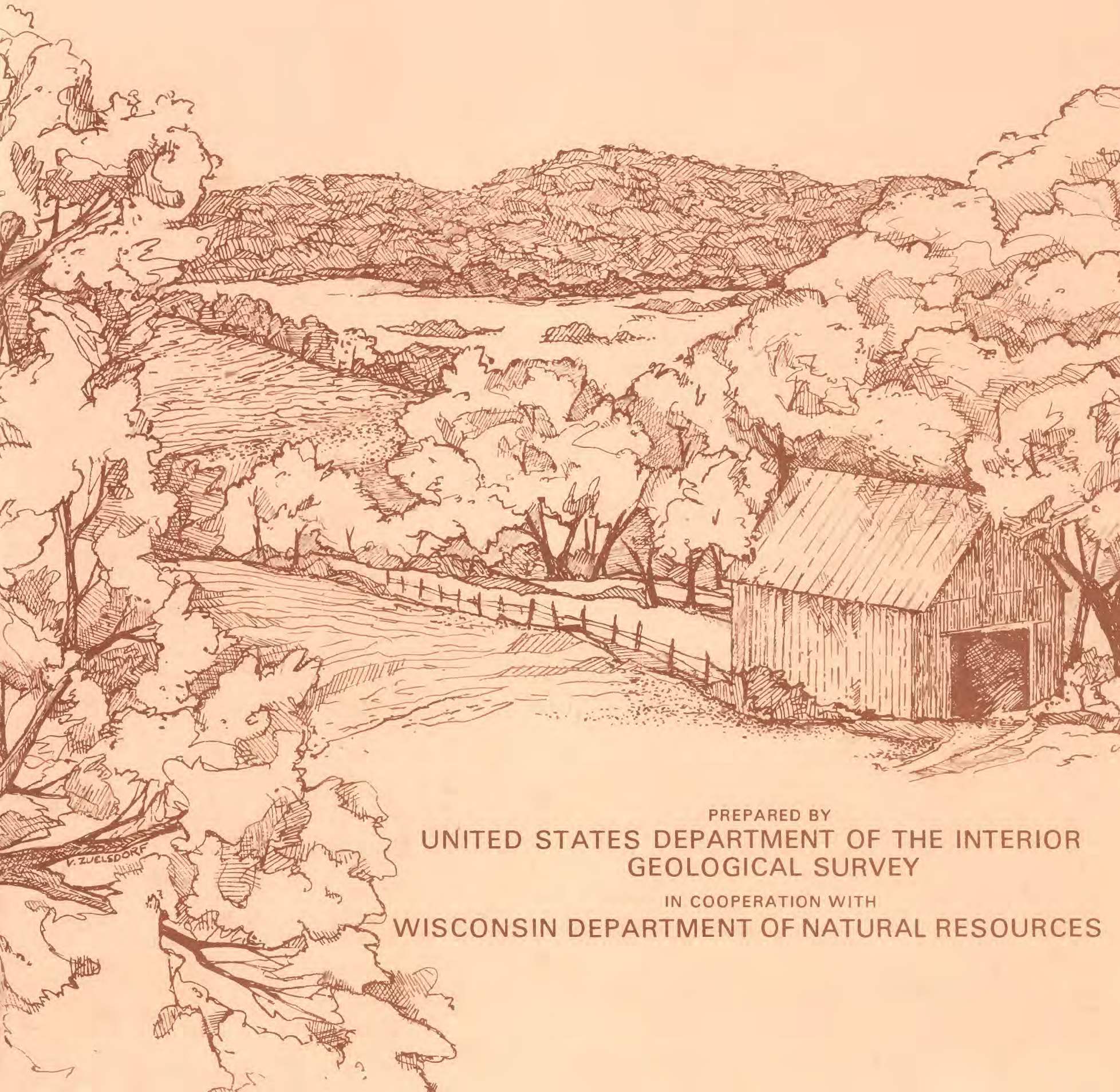




\begin{tabular}{|c|c|c|c|c|}
\hline \multicolumn{2}{|r|}{$\begin{array}{l}\text { REPORT DOCUMENTATION } \\
\text { PAGE }\end{array}$} & 1. REPORT NO. & \multicolumn{2}{|c|}{ 3. Recipient's Accession No. } \\
\hline \multirow{2}{*}{\multicolumn{3}{|c|}{$\begin{array}{l}\text { 4. Titie and Subtitle } \\
\text { HYDROLOGY AND WATER QUALITY IN THE NEDERLO CREEK BASIN, } \\
\text { WISCONSIN, BEFORE CONSTRUCTION OF TWO WATER-RETENTION } \\
\text { STRUCTURES }\end{array}$}} & \multicolumn{2}{|c|}{$\begin{array}{l}\text { 5. Report Date } \\
\text { August } 1979\end{array}$} \\
\hline & & & \\
\hline \multicolumn{3}{|c|}{$\begin{array}{l}\text { 7. Author(s) } \\
\text { P. A. Kammerer, Jr., and M. G. Sherrill }\end{array}$} & \multicolumn{2}{|c|}{$\begin{array}{l}\text { 8. Performing Organization Rept. No. } \\
\text { USGS/WRI-79-95 }\end{array}$} \\
\hline \multicolumn{3}{|c|}{$\begin{array}{l}\text { 9. Performing Organization Name and Address } \\
\text { U.S. Geolngival Survey, Water Resources Division } \\
1815 \text { University Avenue } \\
\text { Madison, Wisconsin } 53706\end{array}$} & $\begin{array}{l}\text { 10. Proj } \\
\text { 11. Con } \\
\text { (C) } \\
\text { (G) }\end{array}$ & isk/Work Unit No. \\
\hline \multirow{2}{*}{\multicolumn{3}{|c|}{$\begin{array}{l}\text { 12. Sponsoring Organization Name and Address } \\
\text { U.S. Geological Survey, Water Resources Division } \\
1815 \text { University Avenue } \\
\text { Madison, Wisconsin } 53706\end{array}$}} & \multirow{2}{*}{\multicolumn{2}{|c|}{$\begin{array}{l}\text { 13. Type of Report \& Period Covered } \\
\text { Final } \\
\text { 14. }\end{array}$}} \\
\hline & & & & \\
\hline \multicolumn{5}{|c|}{$\begin{array}{l}\text { 15. Supplementary Notes } \\
\text { Prepared in cooperation with the Wisconsin Department of Natural Resources }\end{array}$} \\
\hline \multicolumn{5}{|c|}{$\begin{array}{l}\text { 16. Abstract (Limit: } 200 \text { words) } \\
\text { The Nederlo Creek basin in southwest wisconsin is the proposed site of two } \\
\text { structures intended to provide recreation and flood protection. } \\
\text { streamflow is fairly constant at base flow, but rapid changes in discharge occur } \\
\text { during periods of snowmelt or heavy rain. Mean annul precipitation is } 32.5 \text { inches, and } \\
\text { mean annual runoff is } 6.4 \text { inches. } \\
\text { The water is a hard calcium magnesium bicarbonate type. Dissolved-oxygen } \\
\text { concentrations in the stream are lowest during the sumer when nighttime lows are } \\
\text { generally between } 7 \text { and } 8 \text { milligrams per liter and daily maximums between } 11 \text { and } \\
12.5 \text { milligrams per } 1 \text { iter. Considerable diurnal water-temperature fluctuation occurs } \\
\text { in summer with daily maximum temperatures occasionally reaching } 26^{\circ} \text {. Estimates of } \\
\text { mean annual total phosphorus and total nitrogen loads fall within the ranges of } \\
0.02 \text { to } 0.07 \text { and } 0.4 \text { to } 0.8 \text { tons per square mile, respectively; mean annual sediment } \\
\text { loads range from } 13 \text { to } 60 \text { tons per square mile. seventy to } 80 \text { percent of the total } \\
\text { phosphorus, } 35 \text { to } 55 \text { percent of the total nitrogen, and } 74 \text { to } 86 \text { percent of the } \\
\text { suspended sediment are transported during periods when surface runoff contributes to } \\
\text { streamflow. }\end{array}$} \\
\hline \multirow{2}{*}{\multicolumn{5}{|c|}{$\begin{array}{l}\text { 17. Document Analysis a. Descriptors } \\
\text { *Hydrologic budget, *Small watersheds, *Preimpoundment, *Water quality, *Wisco } \\
\text { Water temperature, Surface-/ground-water relationships, Sediment yield, Hydrol } \\
\text { cycle, Dissolved oxygen, Hydrogeology, Surface runoff, Base flow, Potentiometr } \\
\text { Geology, Land use } \\
\text { b. Identifiers/Open-Ended Terms } \\
\text { *Nederlo Creek, *Southwestern Wisconsin, "Driftless Area", Trout stream, Total } \\
\text { nitrogen load, Total phosphorus load, Suspended-sediment load }\end{array}$}} \\
\hline & & & & \\
\hline \multirow{2}{*}{\multicolumn{3}{|c|}{$\begin{array}{l}\text { 18. Availability Statement } \\
\text { No restriction on distribution }\end{array}$}} & \multirow{2}{*}{$\begin{array}{l}\text { 19. Security Class (This Report) } \\
\text { UNCLASSIFIED } \\
\text { 20. Security Class (This Page) } \\
\text { UNCLASSIFIED }\end{array}$} & $\begin{array}{l}\text { 21. No. of Pages } \\
40\end{array}$ \\
\hline & & & & 22. Price \\
\hline
\end{tabular}




\section{Hydrology and Water Quality in the Nederlo Creek Basin, Wisconsin, Before Construction of Two Water-Retention Structures}

P. A. KAMMERER,JR. AND M. G. SHERRILL

U. S. GEOLOGICAL SURVEY

Water-Resources Investigations 79-95

Prepared in cooperation with the

Wisconsin Department of Natural Resources

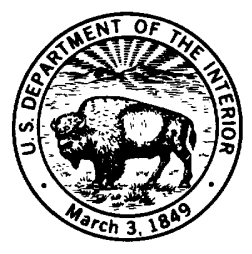

August 1979 


\title{
UNITED STATES DEPARTMENT OF THE INTERIOR
}

\author{
CECIL D. ANDRUS, SECRETARY
}

\section{GEOLOGICAL SURVEY}

H. William Menard, Director

For additional information write to:

U. S. Geological Survey

1815 University Avenue

Madison, Wisconsin 53706 


\section{CONTENTS}

Page

Conversion table $\ldots \ldots \ldots \ldots \ldots \ldots \ldots \ldots \ldots \ldots \ldots \ldots \ldots \ldots \ldots$

Abstract ...............................

Introduction. ........................

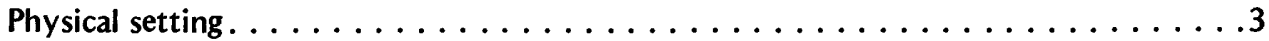

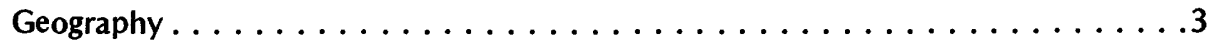

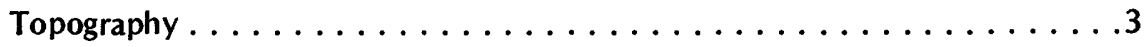

Stream-channel characteristics .....................

Climate ............................ . .

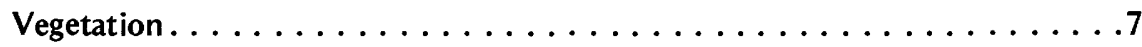

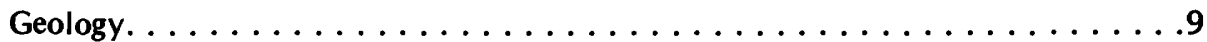

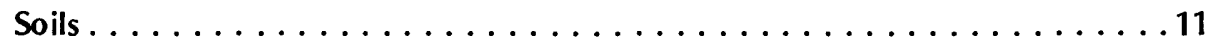

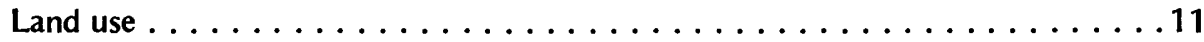

Hydrologic system. . . . . . . . . . . . . . . . . . . . 11

Streamflow ...........................11

Base-flow/drainage-area relationship . . . . . . . . . . . . 15

Flow duration. . . . . . . . . . . . . . . . . . . 15

Hydrograph separation. ....................... 15

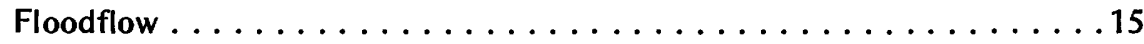

Time of travel. . . . . . . . . . . . . . . . . . . 18

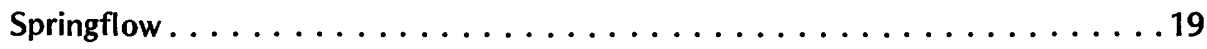

Ground water . . . . . . . . . . . . . . . . . . . 20

Hydrologic budget. . . . . . . . . . . . . . . . . . . 23

Water quality . . . . . . . . . . . . . . . . . . . . . 24

Chemical characteristics . . . . . . . . . . . . . . . . . . . 24

Dissolved oxygen. . . . . . . . . . . . . . . . . . . 27

Water temperature. . . . . . . . . . . . . . . . . . . 30

Transport of dissolved and suspended material . . . . . . . . . . . . . . 32

Conclusions . . . . . . . . . . . . . . . . . . . . . . 34

Literature cited. . . . . . . . . . . . . . . . . . . . . . 34

\section{ILLUSTRATIONS}

Figure 1. Map showing the location of the Nederlo Creek basin in Wisconsin . . . . . 2

2. Map showing topography and locations of water-retention structures . . .4

3. Photographs showing the topography of Johnstown

Valley, March 27,1973 . . . . . . . . . . . . . . . .

4. Diagram showing trace of Nederlo Creek within its flood plain

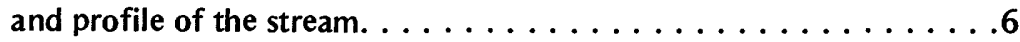

5. Graphs showing changes in stream-channel configuration with time. . . .8

6. Map showing surficial geology . . . . . . . . . . . . . . . 10

7. Map showing soil associations . . . . . . . . . . . . . . . 12

8. Map showing land use, September 1969. . . . . . . . . . . . . . . 13

9. Map showing locations of hydrologic measurement sites . . . . . . . . . 14

10. Graph showing relationship between base flow and drainage area . . . . 16 
11. Graph showing flow duration, water years 1968-75 . . . . . . . . . 17

12. Streamflow hydrographs for wet and dry years . . . . . . . . . 18

13. Graph showing contribution of springflow to base flow, September 1972. . . . . . . . . . . . . . . . . . 20

14. Map showing water table, August and September 1969 . . . . . . . . . 21

15. Water-level hydrographs for observation wells . . . . . . . . . . . 22

16. Map showing location of water-quality measurement sites . . . . . . 25

17. Diagram showing concentration ranges of major

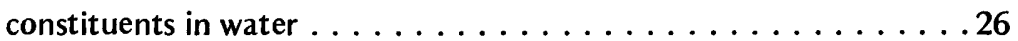

18. Diagram showing nitrate concentrations in the Cambrian

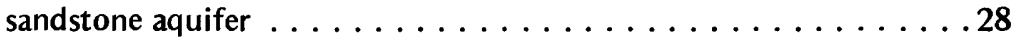

19. Graph showing mean and generalized range of extreme dissolved-oxygen concentrations in Nederlo Creek . . . . . . . . . . 29

20. Graphs showing frequency relationships for summer water temperature in Nederlo Creek . . . . . . . . . . . . . . 31

21. Diagram showing particle-size distribution of suspended sediment. . . . .33

\section{TABLES}

Table 1. Generalized geologic section of exposed bedrock units . . . . . . . . . . .9

2. Annual peak discharges in the Nederlo Creek basin . . . . . . . . . . 19

3. Hydrologic budget, runoff, and mean daily discharge for the

Nederlo Creek basin. . . . . . . . . . . . . . . . . . . 24 


\section{CONVERSION TABLE}

For readers who prefer to use SI units rather than inch-pound units, conversion factors for terms used in this report are listed below.

\author{
Multiply \\ in. (inch) \\ ft (foot) \\ mi (mile) \\ $\mathrm{mi}^{2}$ (square mile) \\ $\mathrm{ft} / \mathrm{mi}$ (foot per mile) \\ ton $/ \mathrm{mi}^{2}$ \\ $\mathrm{ft}^{3} / \mathrm{s}$ (cubic foot per second) \\ acre-ft (acre-foot)
}
By
0.3048
1.609
2.590
0.1894
0.3503

25.40

$2.832 \times 10^{-2}$

$1.233 \times 10^{3}$

\section{To obtain}

$\mathrm{mm}$ (millimeter)

m (meter)

km (kilometer)

$\mathrm{km}^{2}$ (square kilometer)

$\mathrm{m} / \mathrm{km}$ (meter per kilometer)

$\mathrm{t} / \mathrm{km}^{2}$ (metric ton per square kilometer)

$\mathrm{m}^{3} / \mathrm{s}$ (cubic meter per second)

$\mathrm{m}^{3}$ (cubic meter) 


\title{
Hydrology and Water Quality in the Nederlo Creek Basin, Wisconsin, Before Construction of Two Water-Retention Structures
}

\author{
P. A. KAMMERER,JR. AND M. G. SHERRILL
}

\begin{abstract}
The Nederlo Creek basin, in the "Driftless Area" of southwest Wisconsin, is geographically and hydrologically similar to other small basins in the area. Topography is rugged, with approximately 400 feet of relief between the boundary ridge tops and the valley floor. The water-retention structures (a dry floodwater- retention structure and a 43-acre reservoir) are to provide recreation and flood protection for the basin.
\end{abstract}

Streamflow, springflow, precipitation, and groundwater levels were monitored at several sites to describe the hydrologic system. Streamflow is fairly constant at base flow, but rapid changes in discharge occur during periods of snowmelt or heavy rain; recession to base-flow discharge following these events is rapid. Surface runoff is a significant contributor to streamflow only 10 percent of the time.

The mean annual hydrologic budget for water years 1968-72 shows that of the 32.5 inches of precipitation on the basin, 6.4 inches left as runoff and 25.9 inches as evapotranspiration; ground-water storage increased an average of 0.2 inches per year.

The water is a hard calcium magnesium bicarbon- ate type. Concentrations of major constituents in ground water and streams at base flow are similar. but concentrations in the stream generally decrease during periods when surface runoff contributes to streamflow. Dissolved-oxygen concentrations in the stream are generally lowest during the summer; nighttime lows are generally between 7 and 8 milligrams per liter and daily maximums between 11 and 12.5 milligrams per liter. Diurnal water-temperature fluctuations of several degrees are common in streams during summer; daily maximum water temperatures as high as $26^{\circ} \mathrm{C}$ have been measured in some areas, but temperatures this high seldom persist for more than 2 hours. Estimates of mean annual total phosphorus and total nitrogen loads during 1967-74 fall within the ranges of 0.02 to 0.07 and 0.4 to 0.8 tons per square mile, respectively; 70 to 80 percent of the total phosphorus and 35 to 55 percent of the total nitrogen are transported during periods when surface runoff contributes to streamflow.

Mean annual suspended-sediment loads during 1968-74 range from 13 to 60 tons per square mile, with 74 to 86 percent of the total transported during periods when surface water contributes to streamflow. These sediment loads are at the low end of the range previously reported for streams in the "Driftless Area". 


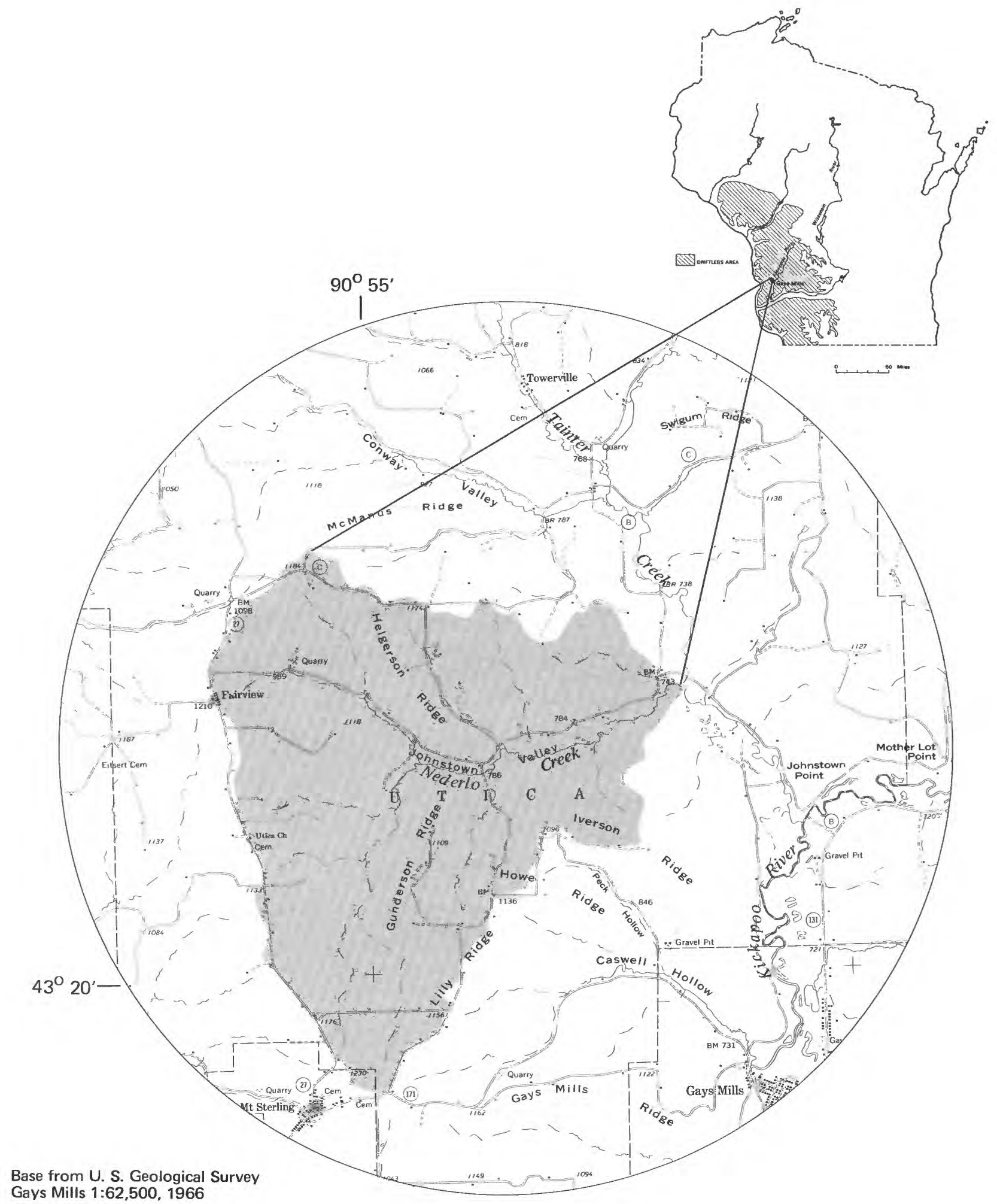

Figure 1. Location of the Nederlo Creek basin in Wisconsin. 


\section{INTRODUCTION}

Several multipurpose reservoirs and flood-control structures have been constructed in Wisconsin, and tentative plans call for several more to be built. Many of these are in southwestern Wisconsin where there are few natural lakes available for recreation, and flash flooding is fairly common in low-lying areas. Effective planning and regulation of these structures requires an understanding of their effects on the water system, but quantitative information on these effects is not generally available.

There is concern that these structures would affect streamflow and downstream water quality and might alter fish habitat, populations, and distribution.

This study was begun in 1967 in cooperation with the Wisconsin Department of Natural Resources (DNR)--its purpose was to evaluate the effects of construction of a reservoir and a floodwater-retention structure on the hydrologic system and water quality in a small basin in southwestern Wisconsin. In 1968, Federal research funds were obtained to provide for more detailed study of water quality and to extend the scope of the study to include aquatic biota.

The study was divided into preconstruction and postconstruction phases; the purpose of this report is to describe preconstruction conditions in the basin as determined during the preconstruction phase of the study conducted in cooperation with DNR. Some information obtained through the use of Federal research funds also is included. A report describing the effects of the structures will be prepared following completion of construction and postconstruction data collection.

The basin chosen for study includes the surface drainage basin of Nederlo Creek (locally used name, not approved by the U.S. Board on Geographic Names). The Nederlo Creek basin is $4 \mathrm{mi}$ northwest of Gays Mills (Crawford County) in southwestern Wisconsin (fig. 1) and has a drainage area of $11.0 \mathrm{mi}^{2}$. It lies in the "Driftless Area" and has a physical and hydrologic environment similar to numerous small basins in the area. Nederlo Creek is a tributary to Tainter Creek, which flows into the Kickapoo River.

The upper reaches of Nederlo Creek are classified as Class 2 trout water by DNR (Wisconsin Conservation Department, 1966, p. 3); this classifiation means that the stream has good water conditions and some natural reproduction of trout, but natural reproduction of trout is not sufficient to maintain a completely wild fishery.

The two water-retention structures planned are part of a comprehensive watershed-protection, floodprevention, and recreation plan for the BlackhawkKickapoo watershed (Crawford and Vernon County Soil and Water Conservation Districts, 1967). A multipurpose (recreation and flood control) reservoir, which is referred to as structure 5 in the plan, is planned for south fork Nederlo Creek (fig. 2). The reservoir at structure 5 will have a total storage capacity of 1,425 acre-ft; the area of the recreation pool will be 43 acres, and the maximum water depth will be $44 \mathrm{ft}$. A second structure (structure 6, fig. 2), on north fork Nederlo Creek, is a single-purpose, floodwater-retention structure with a total storage capacity of 263 acre-ft. Construction of structure 6 began in July 1974 and was completed in November 1975.

The cooperation and assistance of many local residents and property owners have aided in this investigation. The authors thank Messrs. Edwin Nederlo, Lewis Danielson, Everett Kvamme, and James Bauers for access to their properties and for their cooperation in the collection of data. Special thanks also are extended to Messrs. Ronald Forseth and Mark Saegrove for their assistance in maintaining temperature and precipitation recorders. Numerous others are acknowledged for allowing access to their property for occasional hydrologic measurements.

\section{PHYSICAL SETTING}

\author{
GEOGRAPHY \\ Topography
}

The project area has a rugged mature topography characterized by well-developed dendritic drainage consisting of flat-bottomed valleys separated by steep-walled, slightly rounded ridges (fig. 2).

The altitude of the drainage divide of the Nederlo Creek basin is about 1,200 ft; the floor of Johnstown Valley is about $400 \mathrm{ft}$ lower than the ridge tops.

Photographs in figure 3 llustrate the topography of the valley near the two structures; the photographs show Johnstown Valley below the confluence of the forks of Nederlo Creek and tributary valleys near the sites of structures 5 and 6 . The camera placement for the photographs is shown in figure 2.

The flood plain of Nederlo Creek occupies most of the floor of Johnstown Valley and is fairly typical of flood plains in neighboring valleys. The flood plain, which consists of stream-deposited material, is fairly flat, with no evidence of natural levees or terraces. The approximate extent of the Nederlo Creek flood plain and the present perennial channels of Nederlo Creek and its tributaries are shown in figure 4.

\section{Stream-Channel Characteristics}

The configuration of the channel of Nederlo Creek and its major tributaries ranges from fairly straight to meandering. The channel may be divided into distinct reaches based on configuration. South fork 


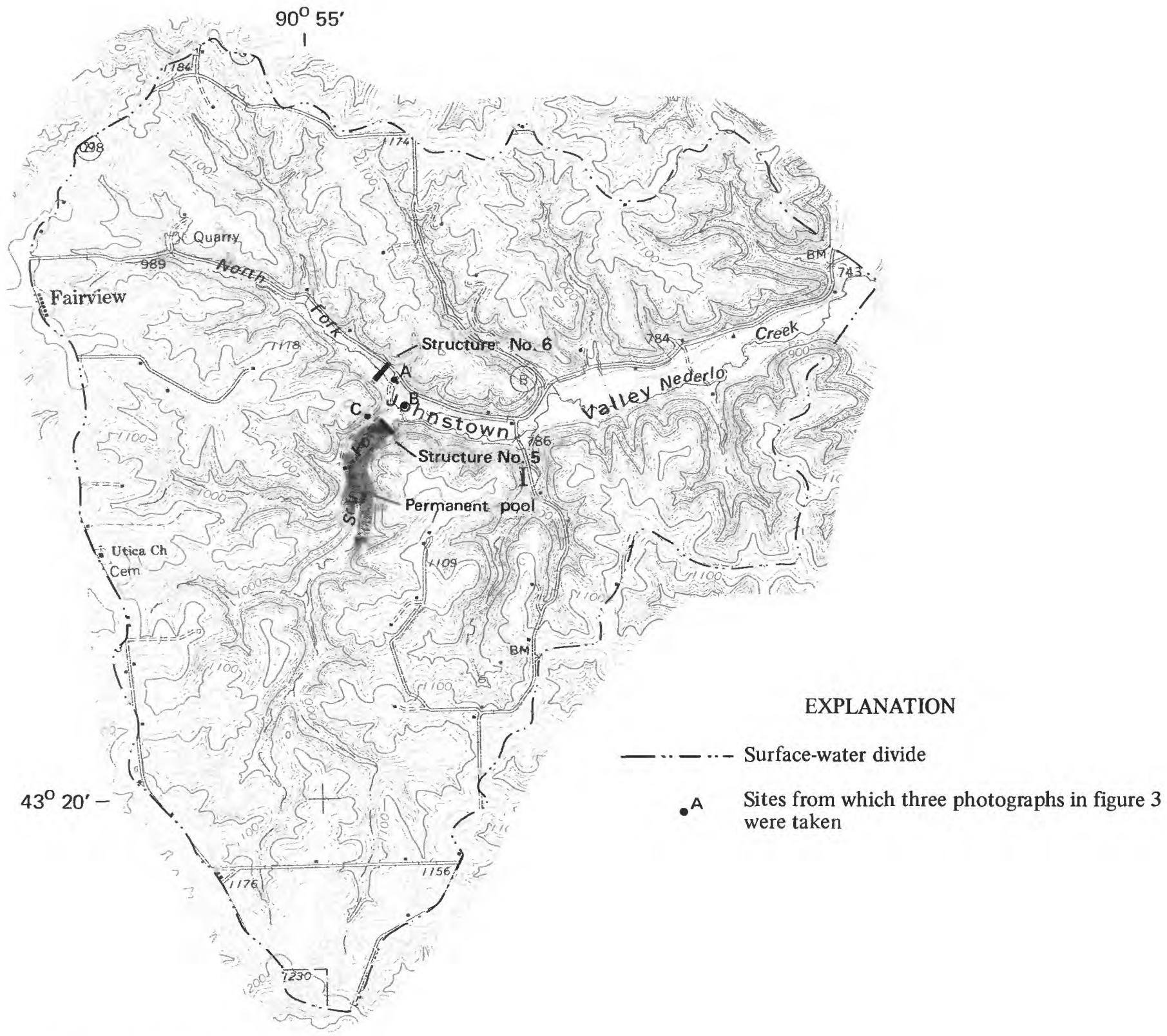

Base from U. S. Geological Survey

Gays Mills 1:62,500, 1966

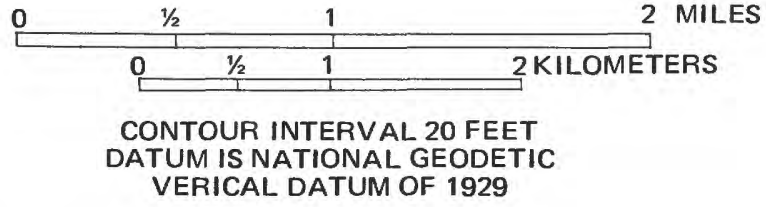

Figure 2. Basin topography and locations of water-retention structures. 
North fork Johnstown Valley. View is northwest from point $A$, figure 2 .
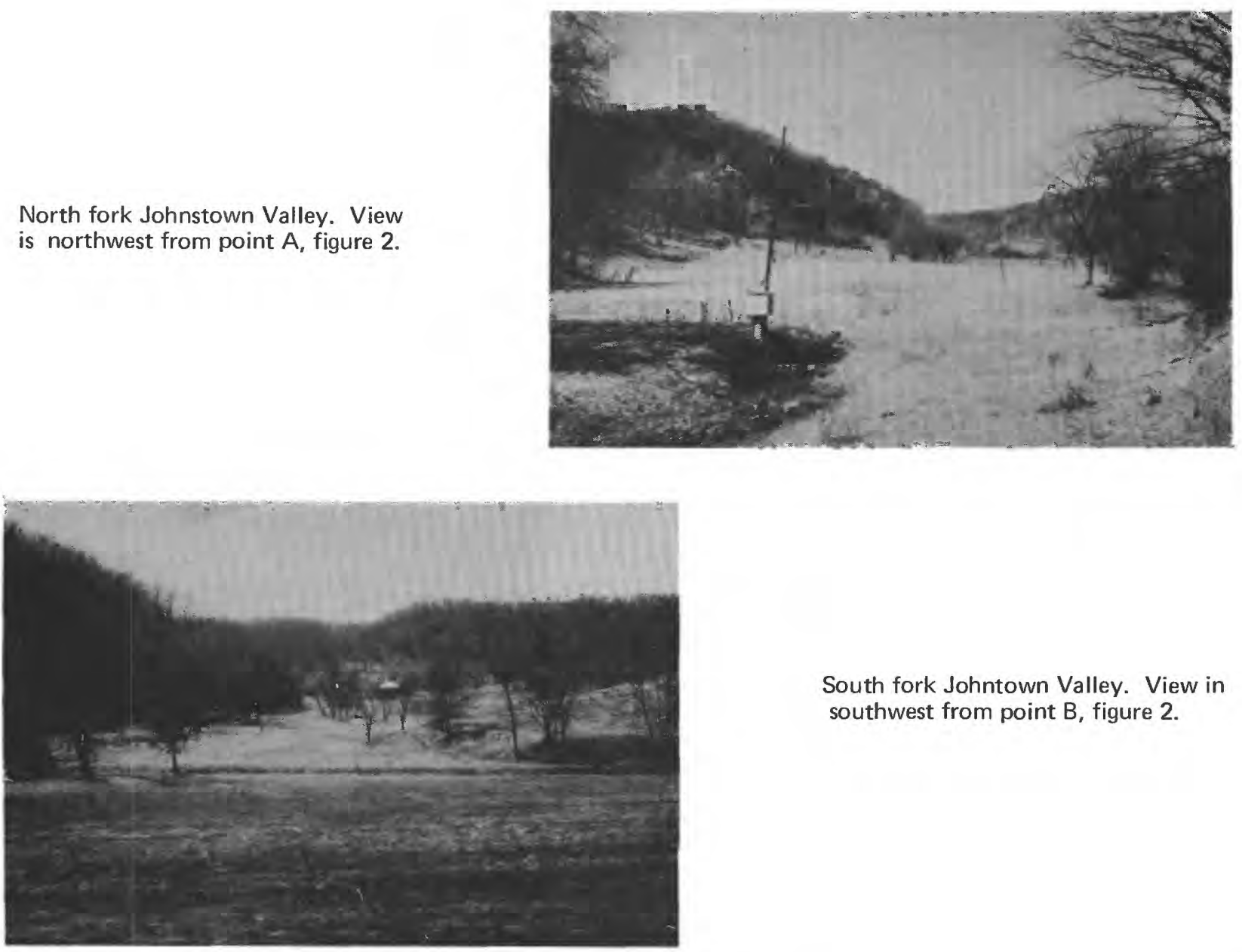

South fork Johntown Valley. View in southwest from point $B$, figure 2 .

Johnstown Valley. View is east from point C, figure 2.

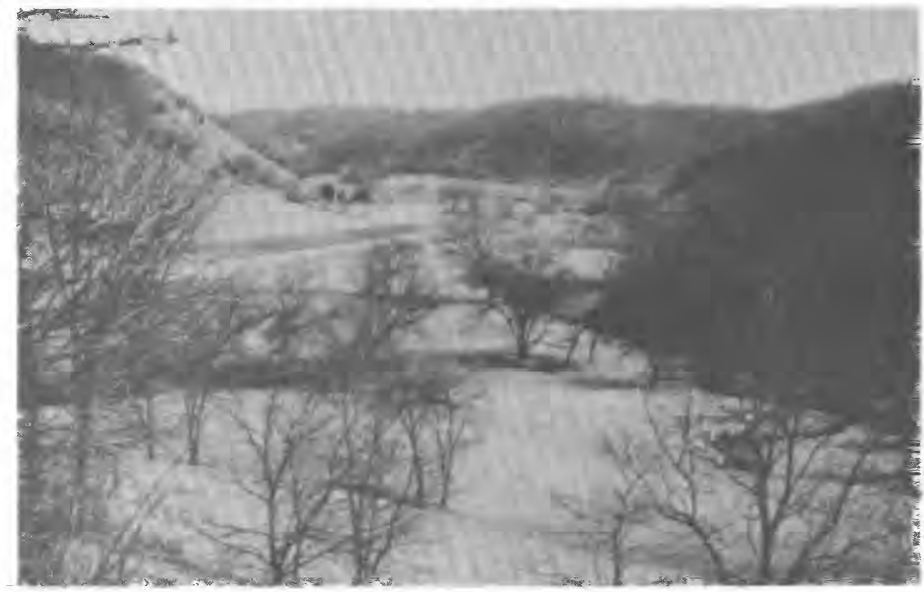

Figure 3. Photographs showing the topography of Johnstown Valley, March 27, 1973. 


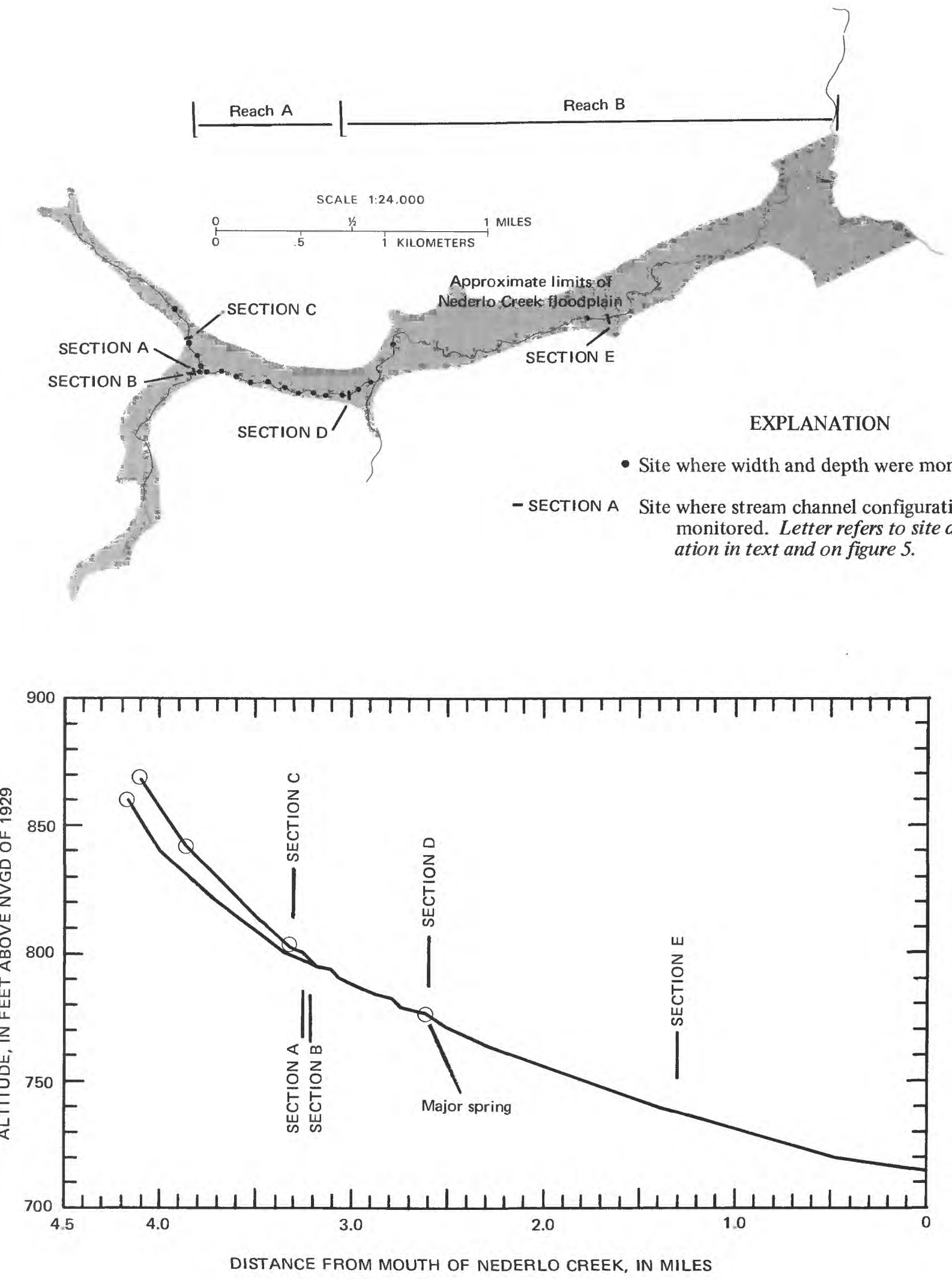

Figure 4. Trace of Nederlo Creek within its flood plain and profile of the stream. 
Nederlo Creek and the lower reach of the main stem (reach B, fig. 4) are fairly sinuous, and north fork Nederlo Creek and the upper reach of the main stem (reach A, fig. 4) are fairly straight.

The straightness of north fork Nederlo Creek and reach $A$ of the main stem may be due to physical factors that restrict shifting of the channel in these reaches. North fork Nederlo Creek has a steep gradient and a narrow flood plain bounded by steep valley walls. The flood plain of reach $A$ slopes to the south, restricting the stream channel to the south side of the valley.

The flood plains of south fork Nederlo Creek and reach $B$ of the main stem are fairly level in cross section and are of sufficient width to permit meandering of the stream.

The stream profile of Nederlo Creek and its tributaries in figure 4 shows the large change in slope between the mouth and the headwaters. The slope varies from about $15 \mathrm{ft} / \mathrm{mi}$ near the mouth to more than $90 \mathrm{ft} / \mathrm{mi}$ in the upper reach of north fork Nederlo Creek.

Stream-channel dimensions and streambank erosion have been monitored by repetitive surveys of cross sections and measurement of the progressive exposure of steel stakes driven laterally into streambanks.

The widths and depths of north fork Nederlo Creek and reach $A$ of the main stem have been measured twice annually at 19 cross sections since 1970 (fig. 4). The cross sections are concentrated in the reaches just downstream from structures 5 and 6 where any stream-channel changes caused by the structures are most likely. The mean of average widths and depths of the individual cross sections in each reach may be used as an approximation of the mean width and depth of the reach. The average width of individual cross sections in reach $A$ ranges from 7.6 to $22.0 \mathrm{ft}$; the average depth ranges from 0.22 to $1.05 \mathrm{ft}$. The mean width and depth of reach $A$ (the mean of the average widths and depths of cross sections in the reach) are 12.2 and $0.54 \mathrm{ft}$, respectively. The average width of cross sections in the lower reach of north fork Nederlo Creek ranges from 5.4 to $13.0 \mathrm{ft}$, and the average depth from 0.19 to $0.46 \mathrm{ft}$; the mean width and depth of this reach are 9.6 and $0.29 \mathrm{ft}$, respectively.

Changes in channel configuration have been monitored since 1968 by repetitive surveys at five sites (fig. 4); the sites represent both stable and unstable reaches. Changes in cross section at each of the sites between 1968 or 1969 and 1975 are shown in figure 5.

The two monitoring sites on south fork Nederlo Creek (sites $A$ and $B$ ) are on a meander. Changes at these sites between 1968 and 1975 consist of slumping of the bank on the outside of the meander and deposition on the inside banks. Although the channel has become narrower at both sites, there has been little change in water-surface altitude.

Site C on north fork Nederlo Creek is on a straight stable reach of stream. Both banks are fully covered by vegetation and there is no evidence of slumping or caving.

Monitoring site $D$ is on a reasonably straight reach of stream, but it became increasingly unstable as a meander formed upstream and moved into the cross section. By 1975, the bank on the outside of the meander had eroded approximately $4 \mathrm{ft}$. The stream channel had become wider and deeper, but the elevation of the water surface was unchanged.

Monitoring site $E$ is on a meander and changed considerably between 1968 and 1975. The bank on the outside of the meander eroded 4 to $8 \mathrm{ft}$, and as much as $1 \mathrm{ft}$ of material was deposited on the inside of the meander. The channel became wider and deeper during the period, but the water-surface altitude increased approximately $0.6 \mathrm{ft}$.

Bank erosion was monitored at 10 sites by measurement of progressive exposure of steel rods driven horizontally into streambanks; the monitoring sites were on the outer banks of stream meanders where the bank was eroding. The amount of bank erosion measured at the sites during $1968-75$ ranged from 0.7 to $2.8 \mathrm{ft}$; the median value for the 10 sites was $1.8 \mathrm{ft}$.

Bank erosion was in excess of $2.8 \mathrm{ft}$ at some of the sites, but measurements were impossible because of loss of the steel stakes during extreme runoff.

\section{Climate}

The climate of the project area is similar to that at Viroqua, $15 \mathrm{mi}$ to the north. Viroqua has a humid, continental-type climate marked by wide temperature extremes within and between seasons (Wisconsin Department of Agriculture, 1961). More than 60 percent of the annual precipitation at Viroqua occurs in May through September. The climate at Viroqua is more representative of the hills than of the valleys; the valleys generally have later springs and earlier fall freezes due to cold air flowing from the hill tops into the valleys during nights of high radiative cooling.

\section{Vegetation}

Microclimatic differences between hills and valleys caused by cold air flows and differences in sunlight and moisture conditions on valley walls (depending on the direction the wall faces) influenced native terrestrial vegetation. Because of this, several plant communities developed, individually and in various gradations with one another, before settlement. Residuals of some of them still persist.

The dry, well-drained ridge tops were predominantly prairie and oak savanna that graded into xeric 

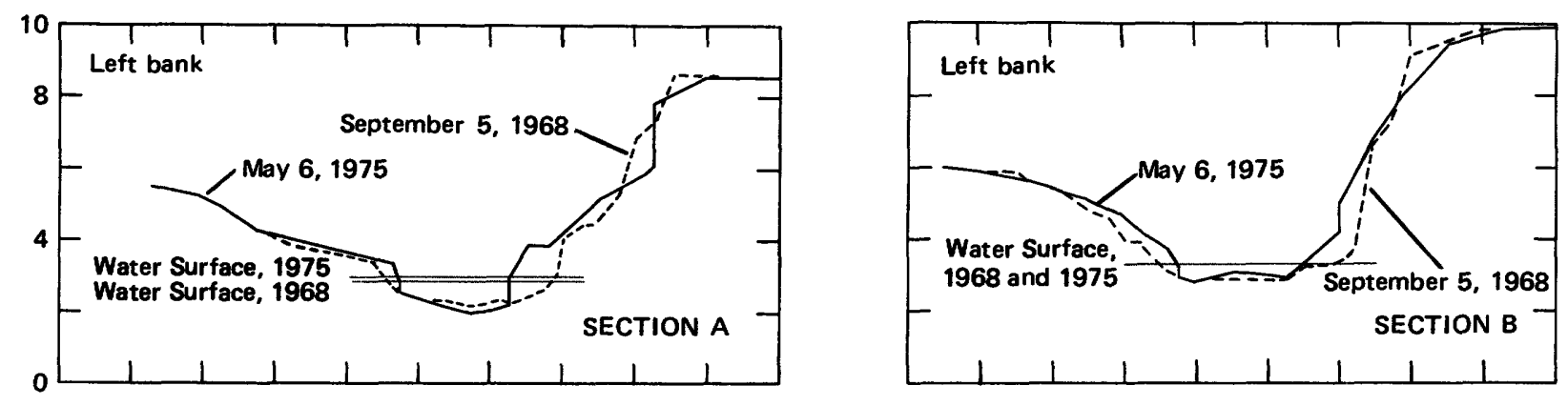

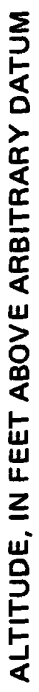
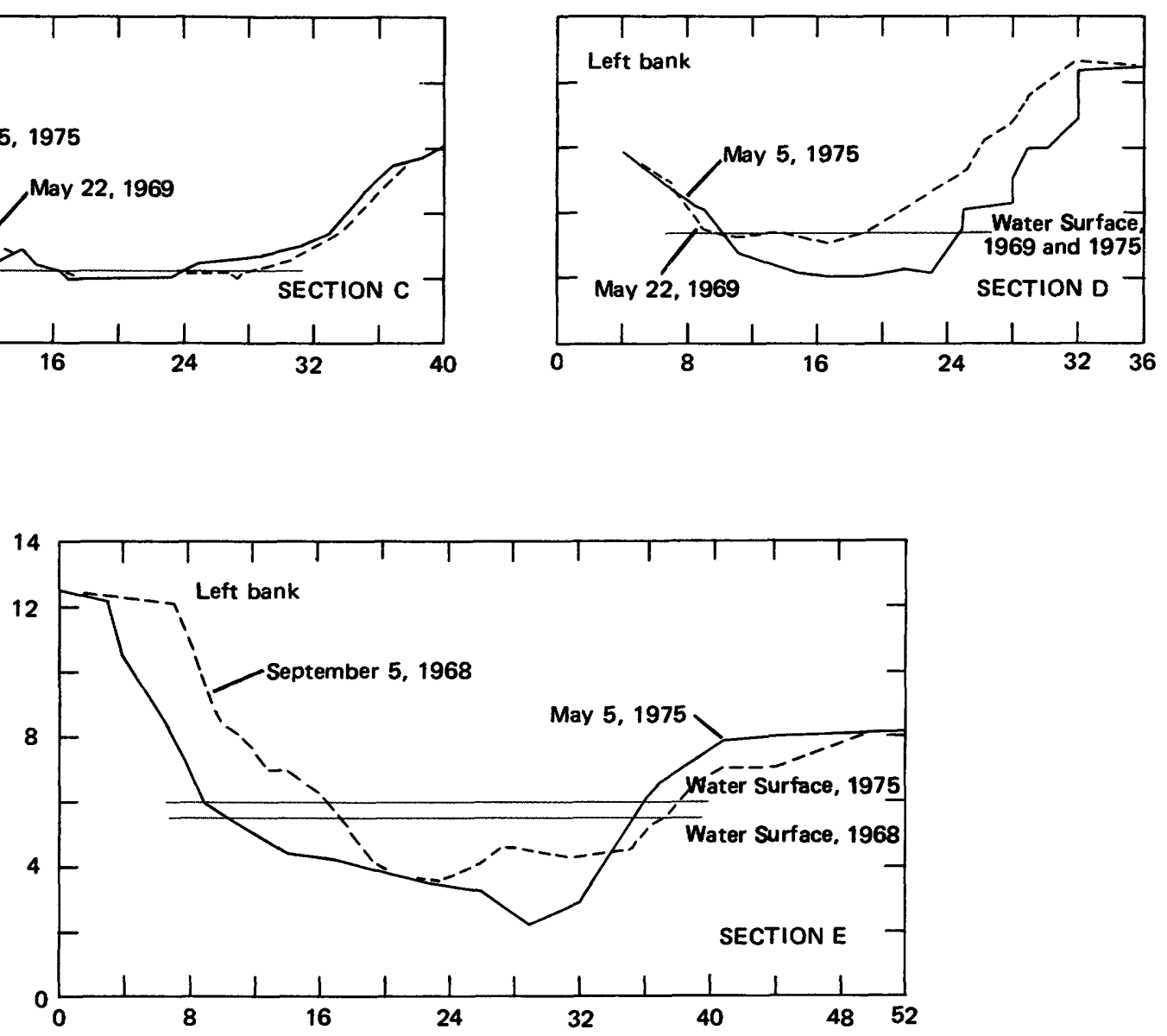

DISTANCE, IN FEET FROM LEFT END OF SECTION VERTICAL EXAGGERATION X 2

Figure 5. Changes in stream channel configuration with time. 
(favoring dry conditions) southern forest on south and west slopes and more mesic (favoring moist conditions) forest on the wetter, cooler north and east slopes. The xeric forests were primarily oak, with some hickory; mesic forests included sugar maple, basswood, and elm (Curtis, 1959, p. 133). One of the largest areas of prairie in the county was around Mount Sterling (Slota and Garvey, 1961, p. 4), which is near the southwest corner of the Nederlo Creek basin.

Valley bottoms were primarily grassland and forest, consisting mainly of soft maple, willow, elm, and river birch (Slota and Garvey, 1961, p. 4).

Settlement of the interior of Crawford County did not begin until after 1840 , but by 1850 settlement was proceeding fairly rapidly (Edwards and others, 1930, p. 3 ). Land clearing and farming in the basin probably began by about 1850 , and settlement caused considerable change in the native vegetation. The prairie and oak savanna gave way to cropland and pasture as much of the original timber was cut.

The second growth timber consists mainly of reestablished members of the xeric forest (predominantly oaks with lesser quantities of hickory, birch, aspen, and boxelder) and several invaders from the mesic forest (mostly sugar maple and basswood) (Curtis, 1959, p. 133).

\section{GEOLOGY}

Bedrock in the Nederlo Creek basin is composed of relatively flat-lying sedimentary rocks of Cambrian and Ordovician age. It is overlain by a few feet of soil on the ridges and hillsides and by thicker alluvium in the valley bottoms, as much as $20 \mathrm{ft}$, perhaps more.
The oldest bedrock penetrated by wells is the Cambrian Dresbach Group, a fine- to medium-grained dolomitic sandstone containing much fine sand and silt. The Franconia Sandstone, the oldest exposed unit, overlies the Dresbach Group. A generalized geologic section showing the altitude, thickness, and lithology of the exposed rock units is given in table 1; the surface geology is shown in figure 6 .

The surface drainage pattern is not controlled by joint orientation. A survey of approximately 160 joints in bedrock units in and near the basin failed to reveal any significant pattern in joint orientation. The joints surveyed were generally vertical and were distributed between the three principal rock units, the St. Lawrence Formation, Jordan Sandstone, and Prairie du Chien Group. An attempt was made to relate joint orientation to the drainage pattern of Nederlo Creek on the theory that the stream would downcut along the joints.

In Johnstown Valley, the bedrock is overlain by alluvium of Pleistocene and Holocene age, consisting of silty and sandy gravel overlain by silt and sandy, clayey silt. The age of the more recent deposits may be inferred from a radiocarbon age determination made by the U.S. Geological Survey's radioisotope laboratory on a birch log found buried at the interface between the silty, sandy gravel and the more recent deposits at streamflow-monitoring site 60 (fig. 9). The age of the wood sample (Lab No. 2386) was $1130+200$ years BP (before present). The log was covered by approximately $6 \mathrm{ft}$ of Holocene deposits consisting of dark-colored sandy, clayey silt from the prairie-woodland environment indigenous to the area before cultivation. These deposits were overlain by $2 \mathrm{ft}$ of lighter colored silt derived primarily from loess washed down from the uplands, probably since the start of cultivation (about 1850).

Table 1. Generlaized geologic section of exposed bedrock units

\begin{tabular}{|c|c|c|c|c|}
\hline $\begin{array}{l}\text { Geologic } \\
\text { age }\end{array}$ & $\begin{array}{l}\text { Geologic } \\
\text { unit }\end{array}$ & $\begin{array}{l}\text { Dominat } \\
\text { lithology }\end{array}$ & $\begin{array}{c}\text { Approximate } \\
\text { altitude } \\
\text { (NGVD of 1929) }\end{array}$ & $\begin{array}{c}\text { Approximate } \\
\text { thickness } \\
\text { (ft) }\end{array}$ \\
\hline \multirow{3}{*}{$\begin{array}{l}\frac{z}{\Delta} \\
\frac{\Delta}{0} \\
\frac{1}{2} \\
\frac{\pi}{0}\end{array}$} & Platteville Formation & Limestone, fossiliferous; some shale & \multirow{2}{*}{1260} & 20 \\
\hline & St. Peter Sandstone & $\begin{array}{l}\text { Sandstone, medium- to coarse- } \\
\text { grained, massive; some shale near } \\
\text { top }\end{array}$ & & 80 \\
\hline & Prairie du Chien Group & $\begin{array}{l}\text { Limestone, dolomitic, and dolomite; } \\
\text { massive to thin bedded }\end{array}$ & 980 & 200 \\
\hline \multirow{3}{*}{$\frac{z}{\frac{z}{\alpha}}$} & Jordan Sandstone & $\begin{array}{l}\text { Sandstone, fine- to coarse-grained; } \\
\text { mostly massive with some cross } \\
\text { bedding }\end{array}$ & \multirow{3}{*}{845} & 135 \\
\hline & St. Lawrence Formation & Dolomite and siltstone & & 40 \\
\hline & Franconia Sandstone & $\begin{array}{l}\text { Sandstone, glauconitic; some } \\
\text { siltstone and shale }\end{array}$ & & 145 \\
\hline
\end{tabular}




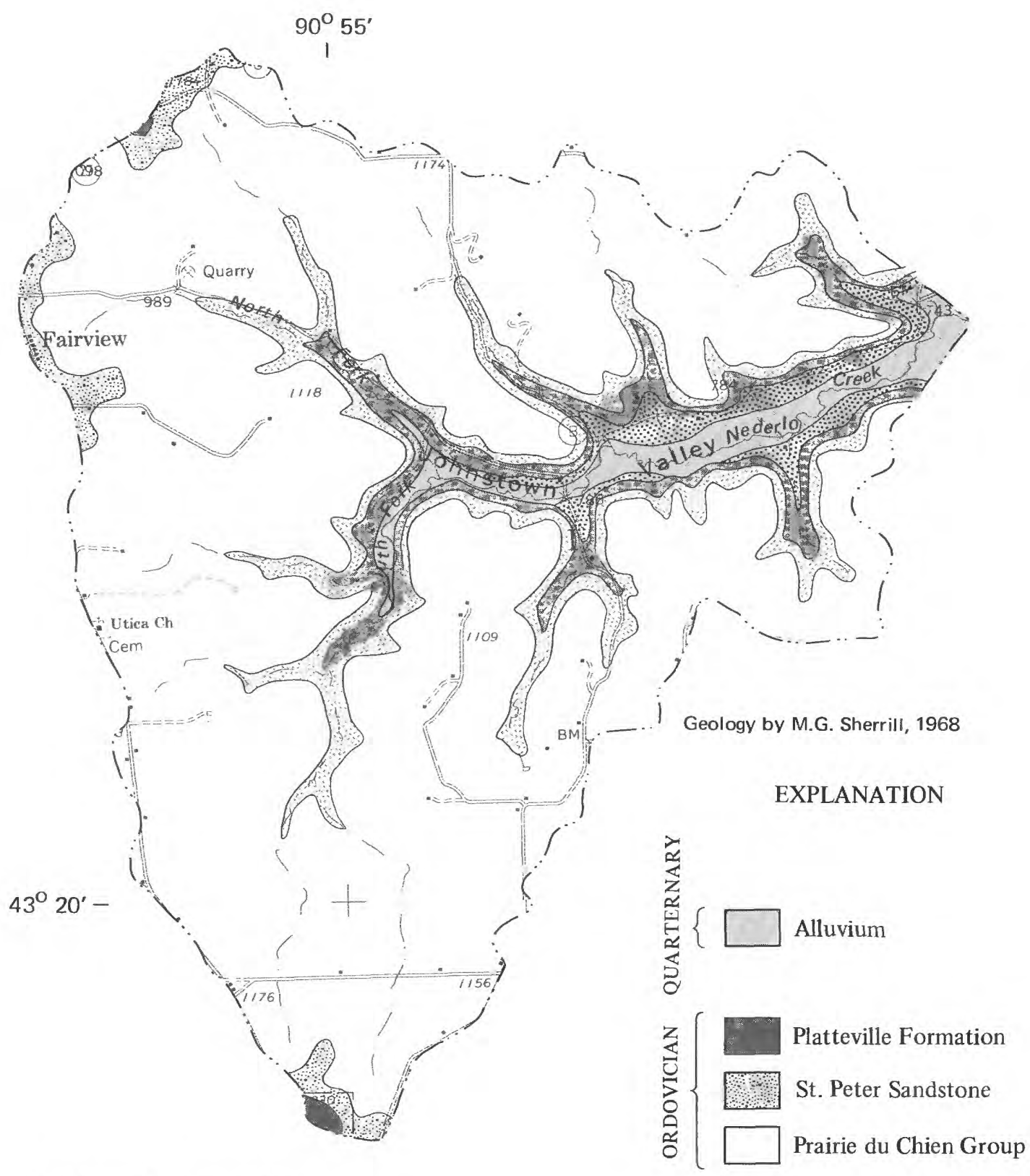

Base from U. S. Geological Survey Gays Mills 1:62,500, 1966
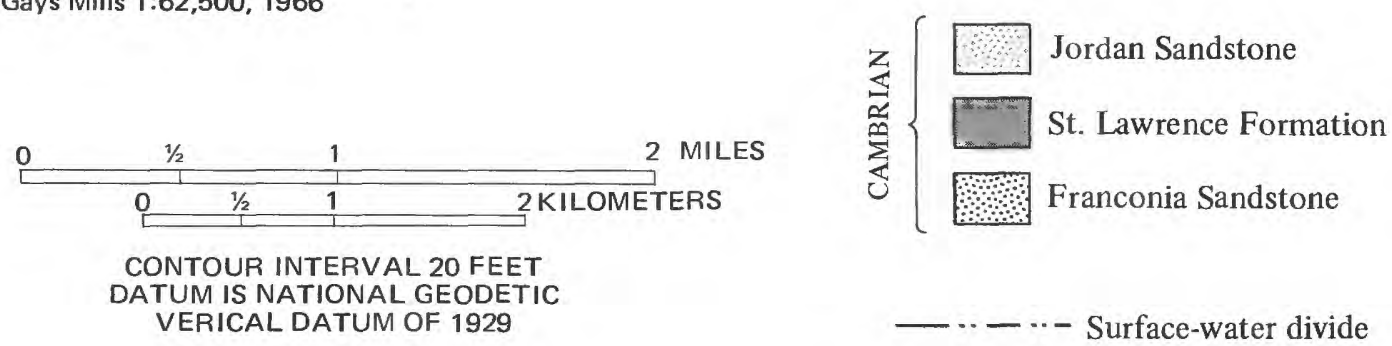

Figure 6. Surficial geology. 
The maximum depths of alluvial material at structures 5 and 6 are approximately 17 and $20 \mathrm{ft}$, respectively (U.S. Soil Conservation Service, written commun., 1970). The depth of the alluvial material increases toward the mouth of Johnstown Valley.

\section{SOILS}

Soil descriptions in a recent soil survey (Slota and Garvey, 1961) were used to divide the soils in the basin into four groups or associations based on texture and parent material; the distribution of these associations is shown in figure 7.

\section{Silty upland soils (Dubuque, Fayette, Downs)}

These soils developed primarily from wind-blown silt on upland ridges and slopes, although the lower part of the Dubuque was derived from limestone. Dubuque soils cover the bulk of the area occupied by silty upland soils; Fayette and Downs soils occupy smaller areas at higher altitudes, generally near the surface drainage divide of the basin. Depth to bedrock is 2 to $6 \mathrm{ft}$ in Dubuque soil and $4 \mathrm{ft}$ or more in the Fayette and Downs. All of the soils in this group are well drained. Infiltration rates are intermediate $(0.1$ to $0.5 \mathrm{in} / \mathrm{h})$ and permeability rates are moderate (0.8 to $2.5 \mathrm{in} / \mathrm{h})$.

Sandy, silty soils (Gale, Hixton, Norden, Lindstrom)

These soils developed from sandstone bedrock or from wind-blown silt overlying sandstone on upland valley slopes. These soils occur over relatively small areas. The soils are well drained, and the depth to bedrock generally ranges from 2 to $5 \mathrm{ft}$. Infiltration rates are intermediate $(0.1$ to $0.5 \mathrm{in} / \mathrm{h})$, and permeability rates are moderate to moderately rapid $(0.8$ to $5.0 \mathrm{in} / \mathrm{h}$ ).

\section{Silty alluvial soils (Arenzville, Chaseburg, Orion, Judson)}

These soils developed on valley floors from silty material washed down from the uplands. The soils range from well drained to poorly drained, and the depth to bedrock ranges from 4 to more than $20 \mathrm{ft}$. Infiltration rates are intermediate $(0.1$ to $0.5 \mathrm{in} / \mathrm{h})$, and permeability, rates are moderate ( 0.8 to $2.5 \mathrm{in} / \mathrm{h})$.

Small areas of sandy, cherty, alluvial material occur near stream channels in the headward end of some of the narrow valleys; these areas are too small to map separately and are included with the silty alluvial soils in figure 7 . Infiltration rates are high (greater than $0.5 \mathrm{in} / \mathrm{h}$ ), and permeability rates are rapid (5.0 to $10.0 \mathrm{in} / \mathrm{h})$.

\section{Stony colluvial land}

This classification consists of a mixture of rocks and soil materials from weathering of bedrock on valley walls and soil materials derived from higher elevations. The material ranges in depth from 0 to $5 \mathrm{ft}$ and is well drained. Infiltration rates are intermediate $(0.1$ to $0.5 \mathrm{in} / \mathrm{h})$, and permeability rates are moderate $(0.8$ to $2.5 \mathrm{in} / \mathrm{h})$.

\section{LAND USE}

Land is devoted to agriculture and farm woodlots except for a small stone quarry in the northwest part of the basin. The community of Fairview (population approximately 30) lies on the western topographic divide. Figure 8, which is compiled from air photos flown in September 1969, shows principal land uses.

Fifty percent of the basin is unirrigated cropland (fig. 8). The three principal crops are hay, oats, and corn, approximately equal amounts of which are planted in the valley. About 60 percent hay or grass, 18 percent oats, and 20 percent corn are planted on the ridges (Ronald Forseth, oral commun., 1973). Tobacco is a major cash crop, but only about 2 percent of the cropland is used for tobacco.

Forty percent of the basin is woodland (fig. 8), mostly on steep slopes between ridges and valley. The woodland is an oak-hickory timber type with some maple, basswood, and birch; the timber is predominantly second growth, and little, if any, is harvestable (Kenneth Hujanen, oral commun., 1973).

Approximately 7 percent of the land is permanent pasture (fig. 8); this is nonwooded land that is generally unsuited for other uses because of steep slopes, poor soil, or poor drainage. The remaining 3 percent of the land is used for roads and buildings.

Livestock is mainly cattle and hogs. In 1973, there were approximately 1,100 dairy cows (including producing milk cows and young stock), 250 beef cattle, and 100 hogs in the basin (Forseth, oral commun., 1973).

\section{HYDROLOGIC SYSTEM}

Streamflow, springflow, precipitation, and groundwater levels were monitored at several sites to describe the hydrologic system. Locations of the monitoring sites are shown in figure 9.

\section{STREAMFLOW}

Streamflow has been monitored at four stations since the 1968 water year; two of the stations are on the main stem of Nederlo Creek, and the other two are located on north fork and south fork Nederlo Creek downstream from the proposed structures.

All streamflow- and springflow-monitoring stations are assigned an 8-digit identification number corresponding to their relative locations in the U. S. Geo- 


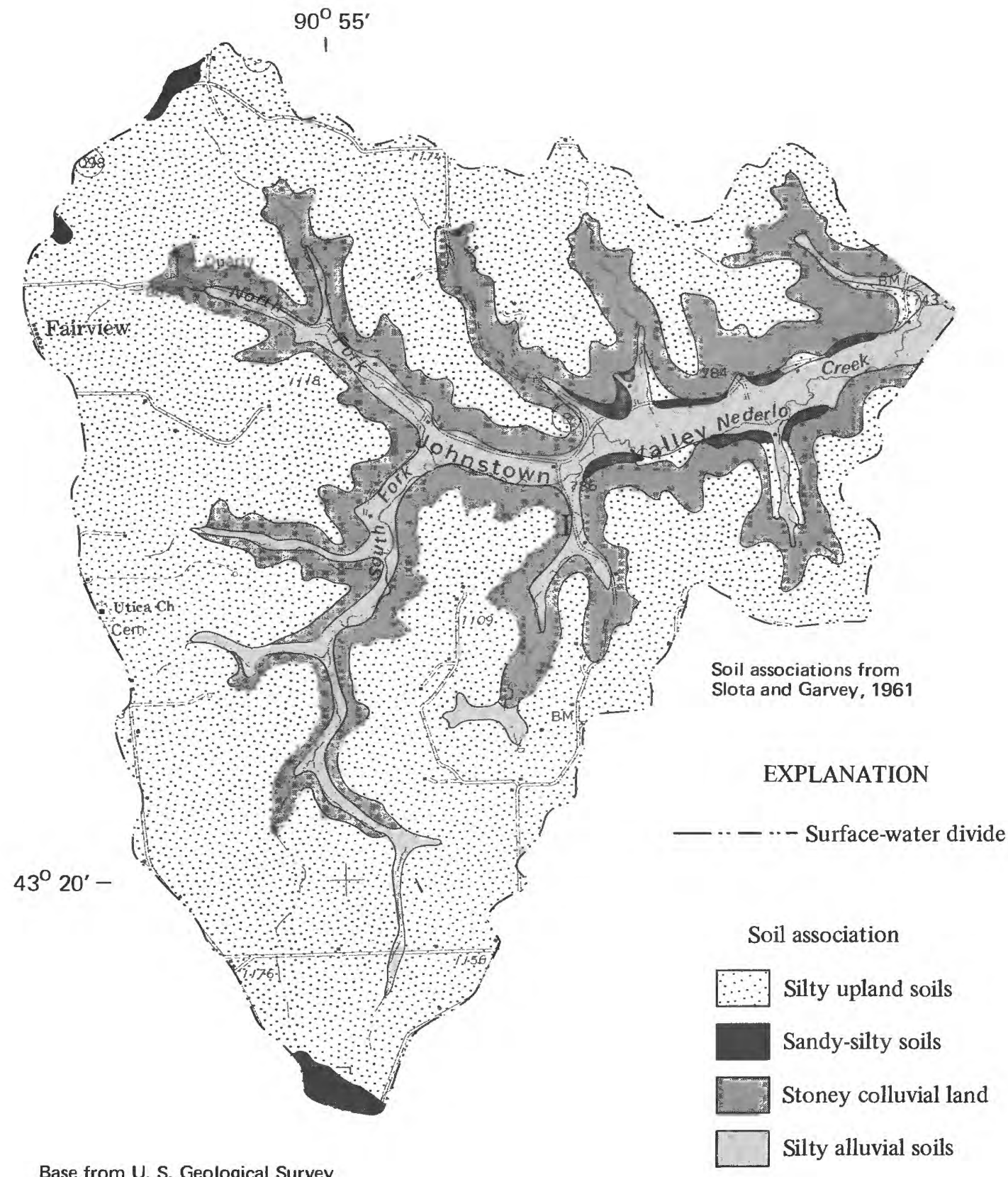

Base from U. S. Geological Survey

Gays Mills 1:62,500, 1966

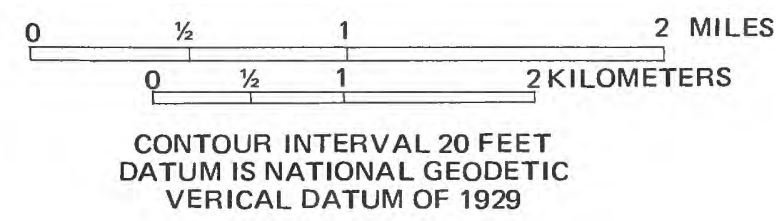

Figure 7. Soil associations. 


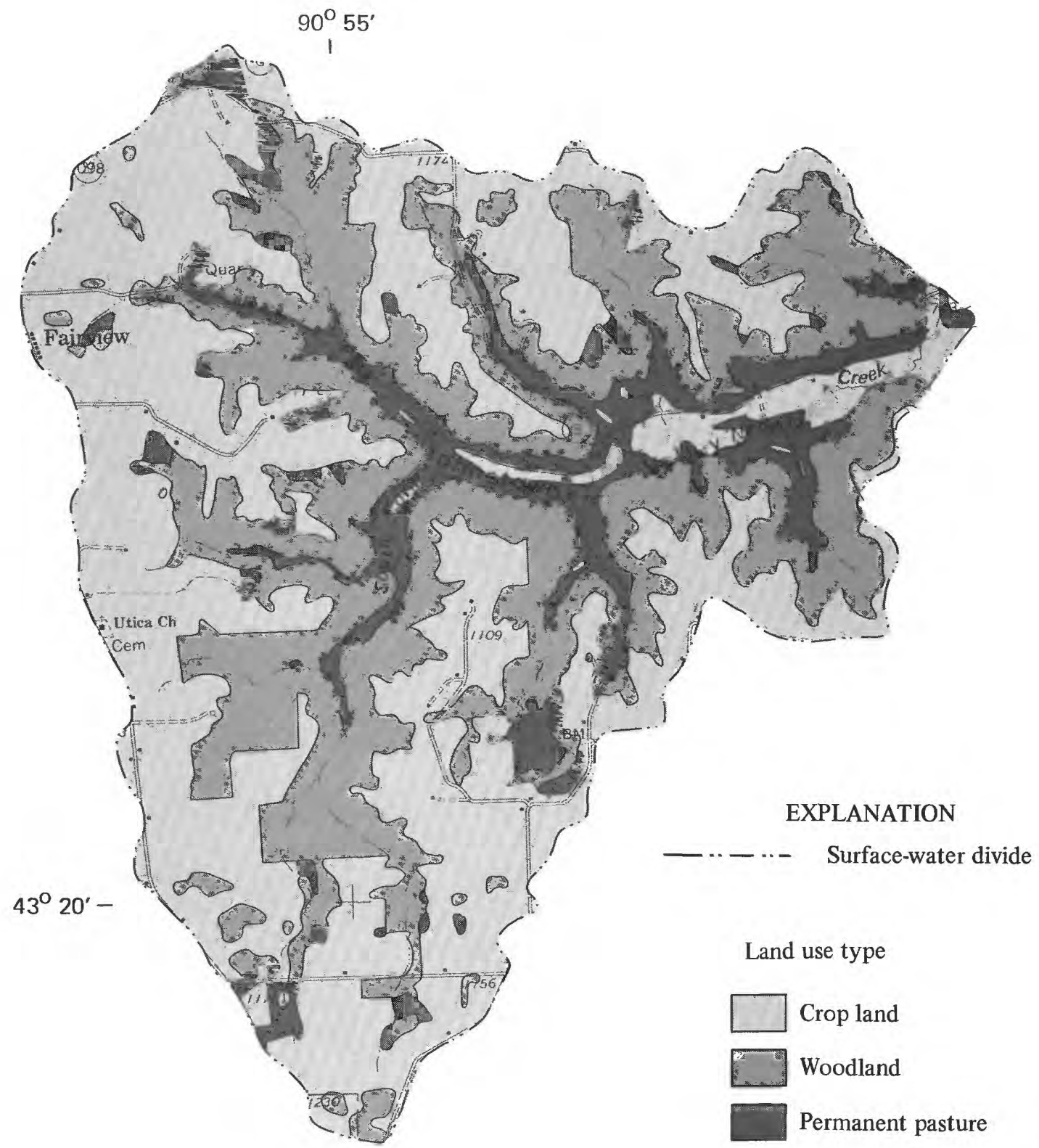

Base from U. S. Geological Survey

Gays Mills 1:62,500, 1966

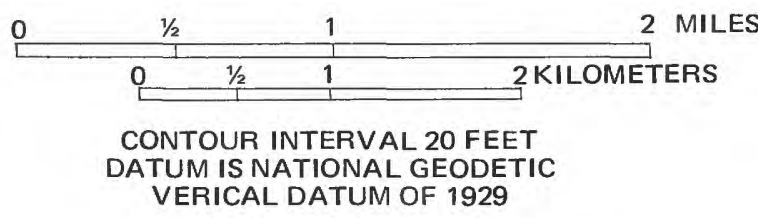

Figure 8. Land use, September 1969. 


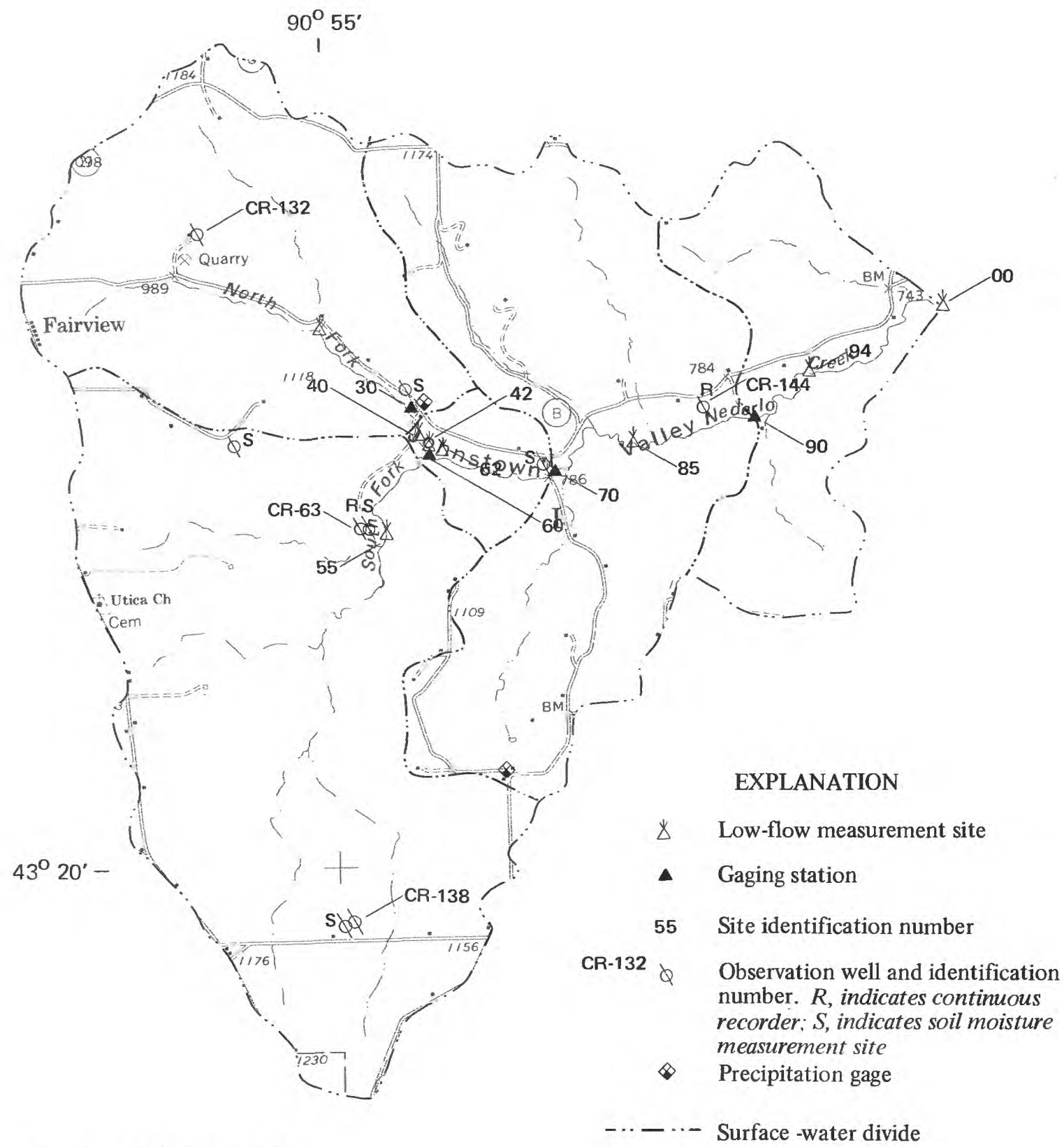

Base from U. S. Geological Survey

Gays Mills 1:62,500, 1966

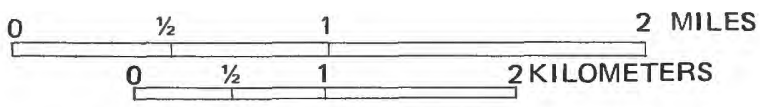

CONTOUR INTERVAL 20 FEET

DATUM IS NATIONAL GEODETIC

VERICAL DATUM OF 1929

Figure 9. Location of hydrologic measurement sites. 
logical Survey's nationwide network of monitoring stations. To avoid repetition, monitoring stations will be identified by only the last two digits of this number; complete identification numbers and the corresponding shortened numbers are listed below.

Name of site

North Fork Nederlo Creek North Fork Nederlo Creek Tributary spring - North Fork Nederlo Creek

North Fork Nederlo Creek South Fork Nederlo Creek South Fork Nederlo Creek Nederlo Creek (main stem) Nederlo Creek (main stem) Nederlo Creek (main stem) Nederlo Creek (main stem) Nederlo Creek (main stem) Nederlo Creek (main stem)

$\begin{array}{cc}\begin{array}{c}\text { Complete } \\ \text { identification no. }\end{array} & \begin{array}{c}\text { Site } \\ \text { identification }\end{array} \\ 05409825 & 25 \\ 05409830 & 30 \\ 05409840 & 40 \\ 05409842 & 42 \\ 05409855 & 55 \\ 05409860 & 60 \\ 05409862 & 62 \\ 05409870 & 70 \\ 05409885 & 85 \\ 05409890 & 90 \\ 05409894 & 94 \\ 05409900 & 00\end{array}$

Streamflow is fairly constant at base flow, but rapid changes in stage occur during snowmelt and heavy rainfall; the following recession to base flow is rapid.

Hydrograph separations and analyses of base-flow/ drainage-area relationships, flow duration, flood flow, and time of travel were prepared to define streamflow characterisitics.

\section{Base-Flow/Drainage-Area Relationship}

The relationship between base flow and drainage area in the Nederlo Creek basin and in adjacent basins is linear. Figure 10 shows the relationship between base flow and drainage area for subbasins within the Nederlo Creek basin and for adjoining basins; the drainage areas range from 1.1 to $14 \mathrm{mi}^{2}$. The measurements shown in figure 10 were made in August 1969 and September 1972 and have a probable recurrence interval of less than 2 years (W. A. Gebert, U.S. Geological Survey, oral commun., 1972).

\section{Flow Duration}

The relationship between streamflow characteristics and physical and hydrologic characteristics may be interpreted from flow-duration curves for streamflow-monitoring stations. Figure 11 shows the duration of various stream discharges. The relatively flat lower parts of the curves indicate the uniform release of ground water from storage; streamflow is primarily ground-water runoff about 90 percent of the time. The steep upper parts of the curves indicate the variability of streamflow during about 10 percent of the time when streamflow is influenced by runoff from rainfall and snowmelt. This variability is due to rapid runoff caused by steep slopes and lack of surface-water storage.

The flow-duration curves in figure 11 include water years 1968-75. Construction work on structure 6 was in progress during the 1975 water year, but the structure had no significant effect on streamflow that year.

\section{Hydrograph Separation}

Separation of streamflow hydrographs into surface- and ground-water runoff components shows that surface runoff is only significant during, and within several hours after, rainfall and snowmelt. This reaffirms what is graphically shown in the flow-duration curves. Although surface runoff is of little significance with respect to time and duration, it can be of considerably greater significance in terms of its contribution to total streamflow.

Hydrograph separations for station 90 show the year-to-year variability of the contribution of surface runoff to streamflow. During water years 1968-72, the part of streamflow at station 90 derived from surface runoff ranged from 23 percent in water year 1968 to 2.6 percent in water year 1971 .

During water year 1971, an example of a dry year, precipitation was 5 in. less than the mean for 1968-72 and was well distributed throughout the year. Total runoff during the 1971 water year was close to the mean value for 1968-72, but this was due to high ground-water runoff for the year; surface runoff accounted for only 2 to 3 percent of the total runoff at stations in the basin.

Water year 1972 (precipitation $1.6 \mathrm{in}$. higher than the mean for 1968-72) was chosen as an example of a wet year even though the precipitation for water year 1968 was 5.1 in. above mean. Precipitation in 1972 was more evenly distributed than in 1968, and both surface- and ground-water runoff were higher in 1972." "Wet" conditions in 1968 were not typical of the entire water year; 50 percent of the surface runoff and 15 percent of the precipitation for the year occurred on just 3 days during the year.

Differences in streamflow hydrographs for station 90 during dry and wet years (1971 and 1972, respectively) are shown in figure 12.

\section{Floodflow}

Flash flooding is the major problem in the Blackhawk-Kickapoo watershed given in the comprehensive work plan for watershed protection, flood prevention, and recreation developed by the Crawford and Vernon County Soil and Water Conservation Districts (Crawford and Vernon County Soil and Water Conservation Districts, 1967). The work plan attributes damage to crops, pastures, roads, bridges, fences, and buildings to "extreme" floods that have occurred every 10 to 12 years since the early 1900's and to smaller floods occurring about every 2 years. 


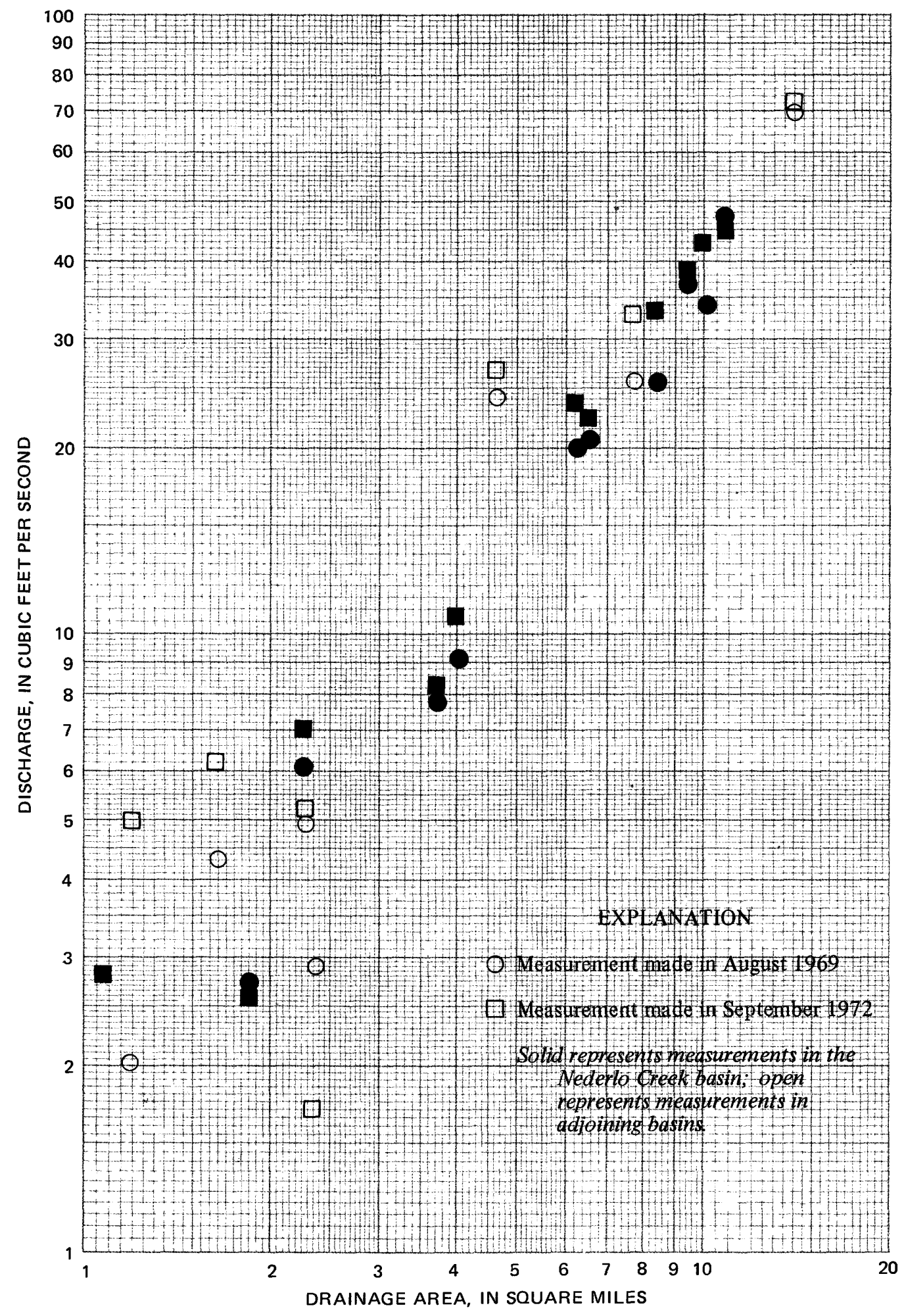

Figure 10. Relationship between base flow and drainage area. 


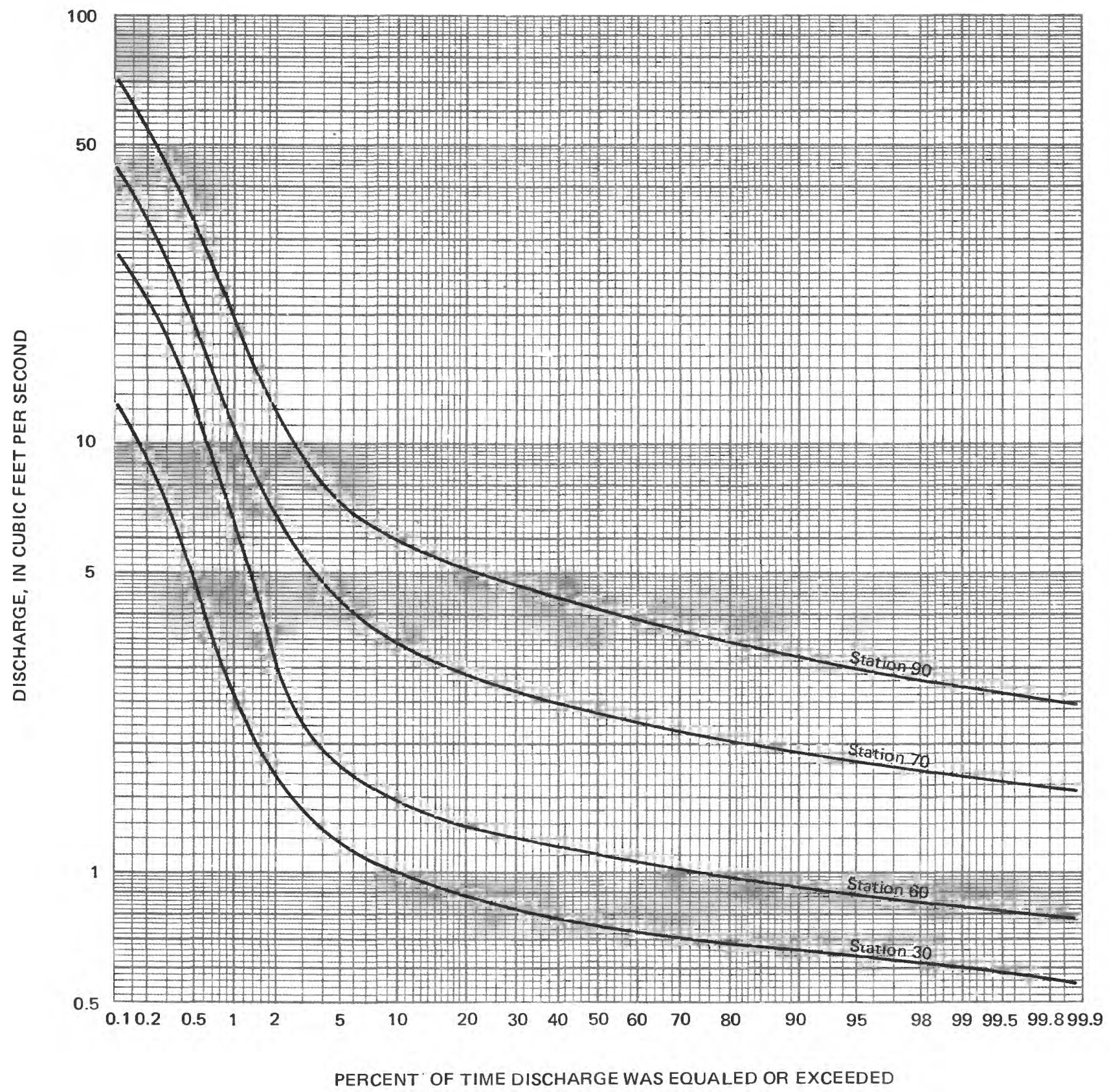

Figure 11. Flow duration, water years 1968-75. 


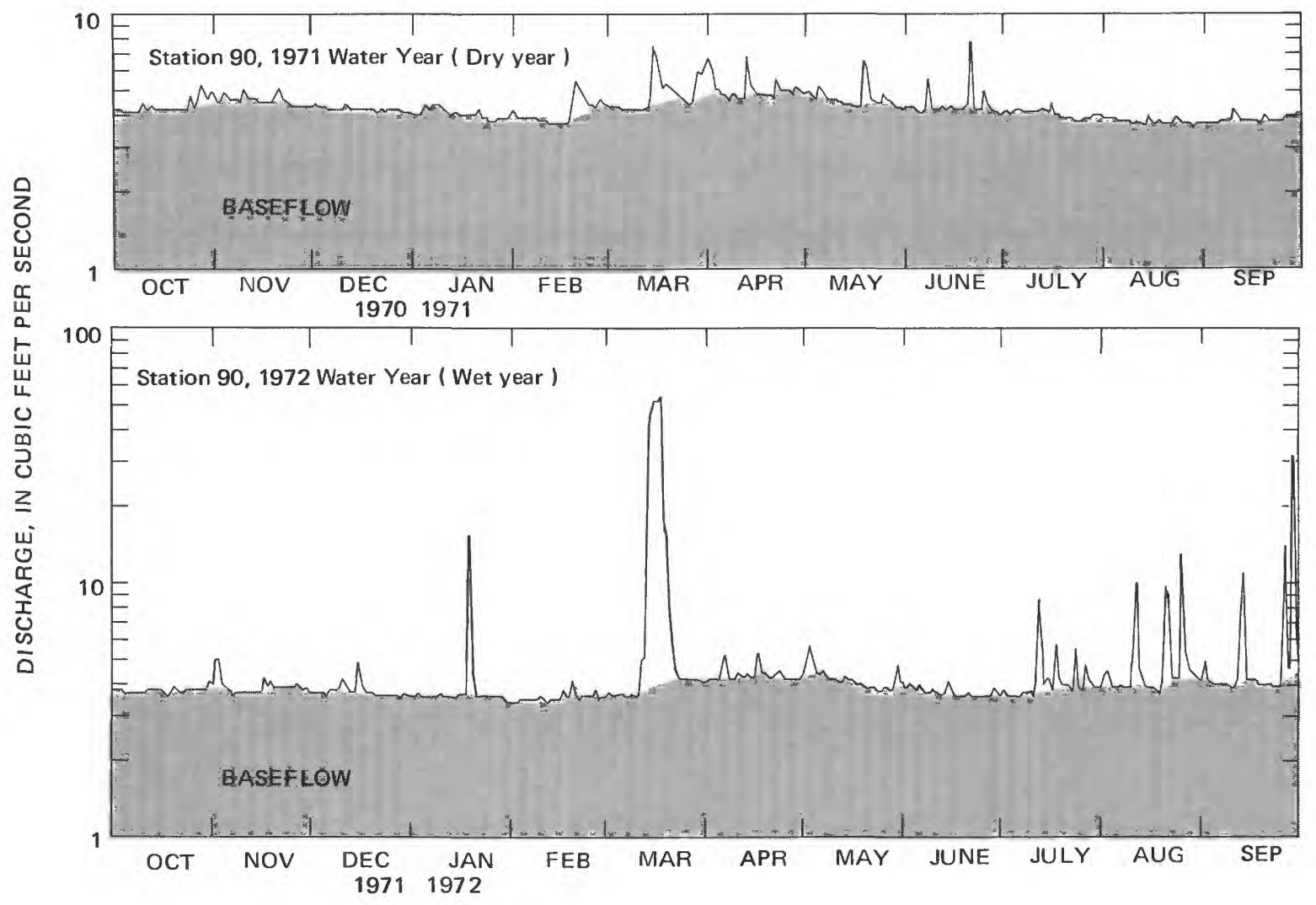

Figure 12. Streamflow hydrographs for wet and dry years.

Since the beginning of the 1968 water year, there has been only one flood of sufficient magnitude to cause Nederlo Creek to overflow its banks. This flood occurred on June 23, 1968, and was caused by runoff from heavy rainfall that fell on soil that had been saturated by $3.57 \mathrm{in}$. of precipitation in the preceding 5 days. An additional 2.16 in. of rain fell on June 23 , with $1.66 \mathrm{in}$. of the total falling in less than half an hour.

Annual peak discharges at streamflow-monitoring stations for water years 1968-73 are shown in table 2, along with their date of occurrence and the approximate rise in stage above the prevailing base-flow stage. The peaks of June 23, 1968, are the peaks of record at all stations. The wide variation in the magnitude of the annual peaks is apparent from the table. All of the annual peaks except those for the 1972 water year were caused by direct runoff from precipitation; the annual peaks in 1972 were caused by snowmelt runoff.

The magnitude and frequency of floods that could be expected in the basin before construction of the flood-control structures was analyzed using the log-Pearson Type III distribution recommended by the U.S. Water Resources Council (1967). Data from water years 1968-73 were used in the analysis. Peak discharges with probable recurrence intervals of 2,5, and 10 years $\left(\mathrm{O}_{2}, \mathrm{Q}_{5}\right.$, and $\left.\mathrm{Q}_{10}\right)$ were computed for each station and are shown below:

$\begin{array}{ccccc} & \text { Station } 90 & \text { Station } 70 & \text { Station } 60 & \text { Station } 30 \\ \mathrm{o}_{2} & 180 \mathrm{ft}^{3} / \mathrm{s} & 120 \mathrm{ft}^{3} / \mathrm{s} & 78 \mathrm{ft}^{3} / \mathrm{s} & 59 \mathrm{ft}^{3} / \mathrm{s} \\ \mathrm{O}_{5} & 660 \mathrm{ft}^{3} / \mathrm{s} & 550 \mathrm{ft}^{3} / \mathrm{s} & 310 \mathrm{ft}^{3} / \mathrm{s} & 210 \mathrm{ft}^{3} / \mathrm{s} \\ \mathrm{O}_{10} & 1,470 \mathrm{ft}^{3} / \mathrm{s} & 1,240 \mathrm{ft}^{3} / \mathrm{s} & 660 \mathrm{ft}^{3} / \mathrm{s} & 380 \mathrm{ft}^{3} / \mathrm{s}\end{array}$

\section{Time of travel}

Time of travel and longitudinal dispersion in the reach downstream from the proposed reservoir on south fork Nederlo Creek (structure 5) were measured in August 1973. Fluorescent dye was placed in south fork Nederlo Creek near the site of proposed structure 5 (upstream from station 60), and dye concentration was monitored at stations 62,70 , and 90 (fig. 9). 
Table 2. Annual peak discharges in the Nederlo Creek basin

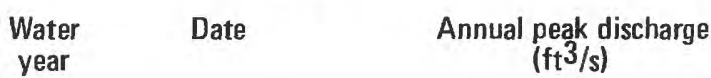

Station 30

$\begin{array}{ll}1968 & \text { June 23 } \\ 1969 & \text { June 26 } \\ 1970 & \text { June 13 } \\ 1971 & \text { June 20 } \\ 1972 & \text { Mar. 15 }\end{array}$

1973 Feb. 1

$\begin{array}{ll}1968 & \\ 1969 & \text { June 23 } \\ 1970 & \text { June 26 } \\ 1971 & \text { July 29 } \\ 1972 & \text { June 24 } \\ 1973 & \text { Mar. 17 } \\ & \text { Sept. 21 }\end{array}$

$\begin{array}{ll}1968 & \text { June 23 } \\ 1969 & \text { June 26 } \\ 1970 & \text { June 13 } \\ 1971 & \text { June 20 } \\ 1972 & \text { Mar. 17 } \\ 1973 & \text { Feb. 1 }\end{array}$

$\begin{array}{ll}1968 & \text { June 23 } \\ 1969 & \text { June 26 } \\ 1970 & \text { June 29 } \\ 1971 & \text { June 20 } \\ 1972 & \text { Mar. 17 } \\ 1973 & \text { Sept. 21 }\end{array}$

545
77
48
4.3
84
35

Station 60

1,080

78
44

7.9

120

95

Station 70

1,840
148
48
10
312
105

Station 90

2,650
239
175
34
233
140

Streamflow was at high base flow. Discharges measured at stations along the study reach and at the mouth of north fork Nederlo Creek (station 42), a tributary to the study reach, were equaled or exceeded less than 15 percent of the time during water year 1968-75 (fig. 11).

Mean traveltimes, time required for passage of the dye, and other pertinent data are given in the following table. The leading and trailing edges of the dye cloud are defined as the points at which dye concentrations were 10 percent of the peak concentration. This avoids inconsistencies caused by the low dye concentrations at the leading and trailing edges of the dye cloud.

$$
\begin{array}{ccccc}
\text { Station } & \begin{array}{c}
\text { Discharge } \\
\left.{ }^{3} / \mathrm{s}\right)
\end{array} & \begin{array}{c}
\text { Miles down- } \\
\text { stream from } \\
\text { structure 5 }
\end{array} & \begin{array}{c}
\text { Mean } \\
\text { traveltime } \\
\text { (hours) }
\end{array} & \begin{array}{c}
\text { Elapsed time } \\
\text { for passage } \\
\text { of dye (hours) }
\end{array}
\end{array}
$$

$\begin{array}{llrcc}42 & 1.7 & -- & -- & -- \\ 60 & 1.2 & -- & -- & -- \\ 62 & 2.9 & 0.10 & 0.5 & 0.4 \\ 70 & 3.1 & .66 & 3.1 & 1.8 \\ 90 & 5.2 & 1.96 & 7.6 & 2.9\end{array}$

\section{Approximate height above normal} base flow stage

(ft)

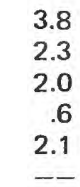

$$
\begin{aligned}
& 4.4 \\
& 2.3 \\
& 1.9 \\
& 1.1 \\
& 2.7 \\
& 1.8
\end{aligned}
$$

$$
\begin{array}{r}
3.6 \\
2.2 \\
1.2 \\
.3 \\
2.8 \\
1.9
\end{array}
$$

The mean velocity of water in each reach was computed using the mean traveltime (traveltime of peak dye concentration) and the length of the reach. The mean velocity in the reach from the injection point (near proposed structure 5) to station 70 was $0.31 \mathrm{ft} / \mathrm{s}$. The mean velocity increased to $0.42 \mathrm{ft} / \mathrm{s}$ between stations 70 and 90 . The slope of the stream channel decreases from $34 \mathrm{ft} / \mathrm{mi}$ between station 62 and 70 to $30 \mathrm{ft} / \mathrm{mi}$ between stations 70 and 90 , so the higher velocity in the lower reach is probably due mainly to the pickup in discharge and the relatively small cross-sectional area of the stream. Discharge only increases from 2.9 to $3.1 \mathrm{ft}^{3} / \mathrm{s}$ between stations 62 and 70, but it increases from 3.1 to $5.2 \mathrm{ft}^{3} / \mathrm{s}$ between stations 70 and 90 .

\section{SPRINGFLOW}

Discharge from springs in bedrock units is a major source of streamflow at base flow. At base flow streamflow consists entirely of ground-water runoff. Figure 13 shows the springflow contribution to base flow measured in September 1972 at springheads along the creek. The streamflow not attributable to springflow is derived from ground-water discharge from the alluvium along the channel. 


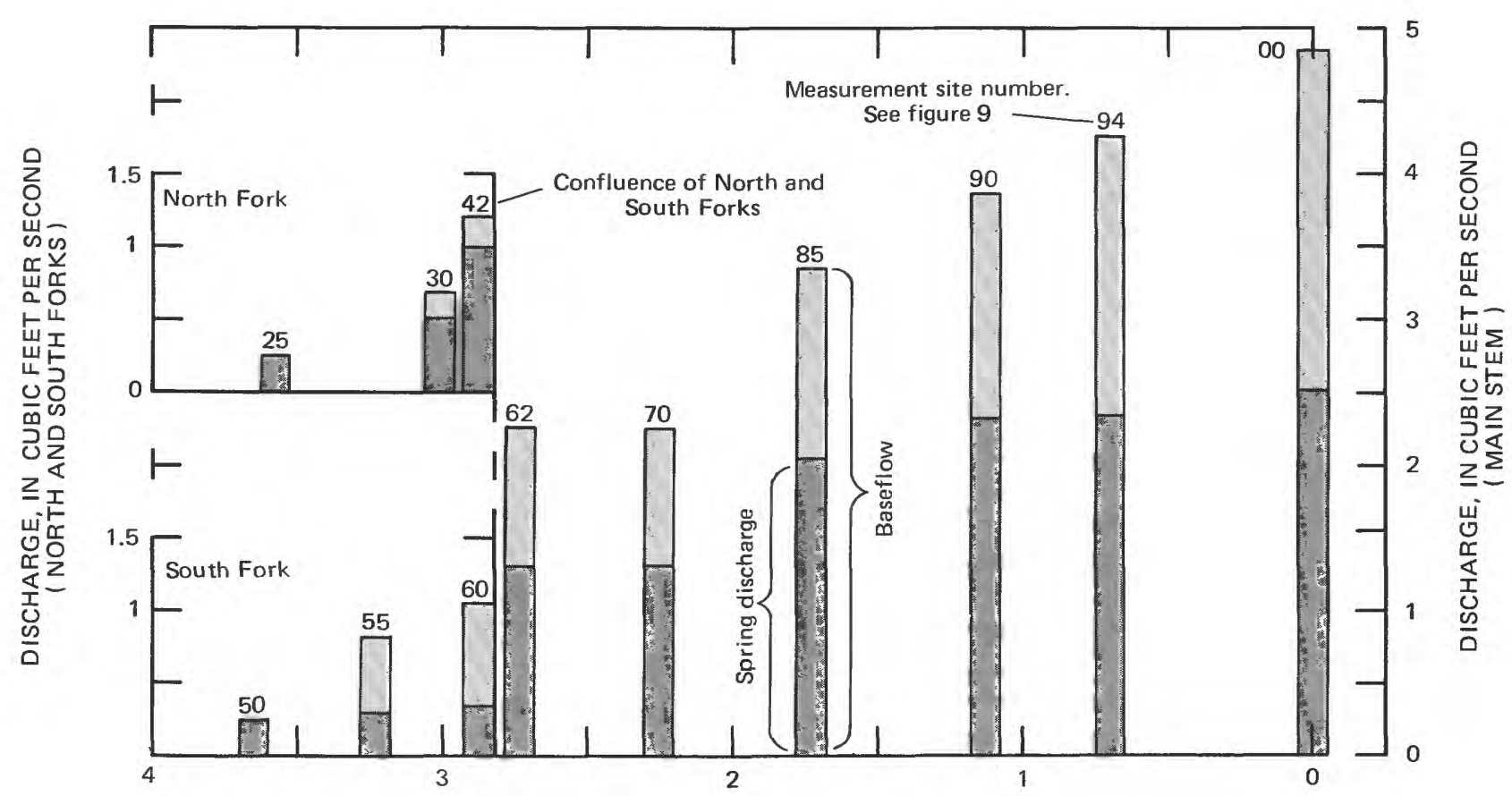

DISTANCE, IN MILES ABOVE MOUTH OF NEDERLO CREEK

Figure 13. Contribution of springs to base flow, September 1972.

North fork Nederlo Creek has the highest springflow contribution of any reach -82 percent of the streamflow at its confluence with south fork Nederlo Creek; the south fork has the lowest springflow contribution - about 30 percent at this point. Streamflow in the main stem is about 60 percent springflow from the confluence of north and south forks to about stream mile 1.1 (station 90, fig. 9): from this point, springflow contribution decreases fairly uniformly to about $\mathbf{5 2}$ percent of streamflow at the mouth.

Springs in the headwaters of the north and south forks emerge near the base of the Jordan Sandstone. The spring at station 40 (fig. 9), which is a major contributor to streamflow in the north fork, emerges at the base of the St. Lawrence Formation. Springs along the main stem are in the upper part of the Franconia Sandstone.

The constancy of discharge from springs is typified by the discharge of the spring at station 40 (fig. 9). The mean daily discharge of this spring for water years $1968-72$ was $0.40 \mathrm{ft}^{3} / \mathrm{s}$, and the extremes during this period were 0.36 and $0.49 \mathrm{ft}^{3} / \mathrm{s}$. Spring discharge generally does not respond directly to precipitation-changes in discharge occur gradually over longer periods of time.

\section{GROUND WATER}

Ground-water bodies are recharged by local precipitation and discharged by springs, seeps, evapotranspiration, and pumping wells. Most ground water discharges as streamflow in Nederlo Creek; pumpage is negligible and evapotranspiration of ground water is small due to the large distance between the root zone and the potentiometric surface over most of the basin.

Water for domestic and farm use is obtained from wells in the uplands and from wells or springs in the valleys. Little information is available on construction of wells in the basin, but most of them are probably obtaining water from Cambrian sandstone and dolomite.

A contour map of the water table is shown in figure 14. The water table has roughly the same configuration as the land surface but is more subdued. The water table lies in Cambrian sandstone under the ridges and in alluvium in the valleys; the general movement of ground water is from water-table highs under the ridges to discharge areas in the valley. The distance between the land surface and the water table ranges from a few feet in the valley to more than $200 \mathrm{ft}$ near the ground-water divide (fig. 14). 


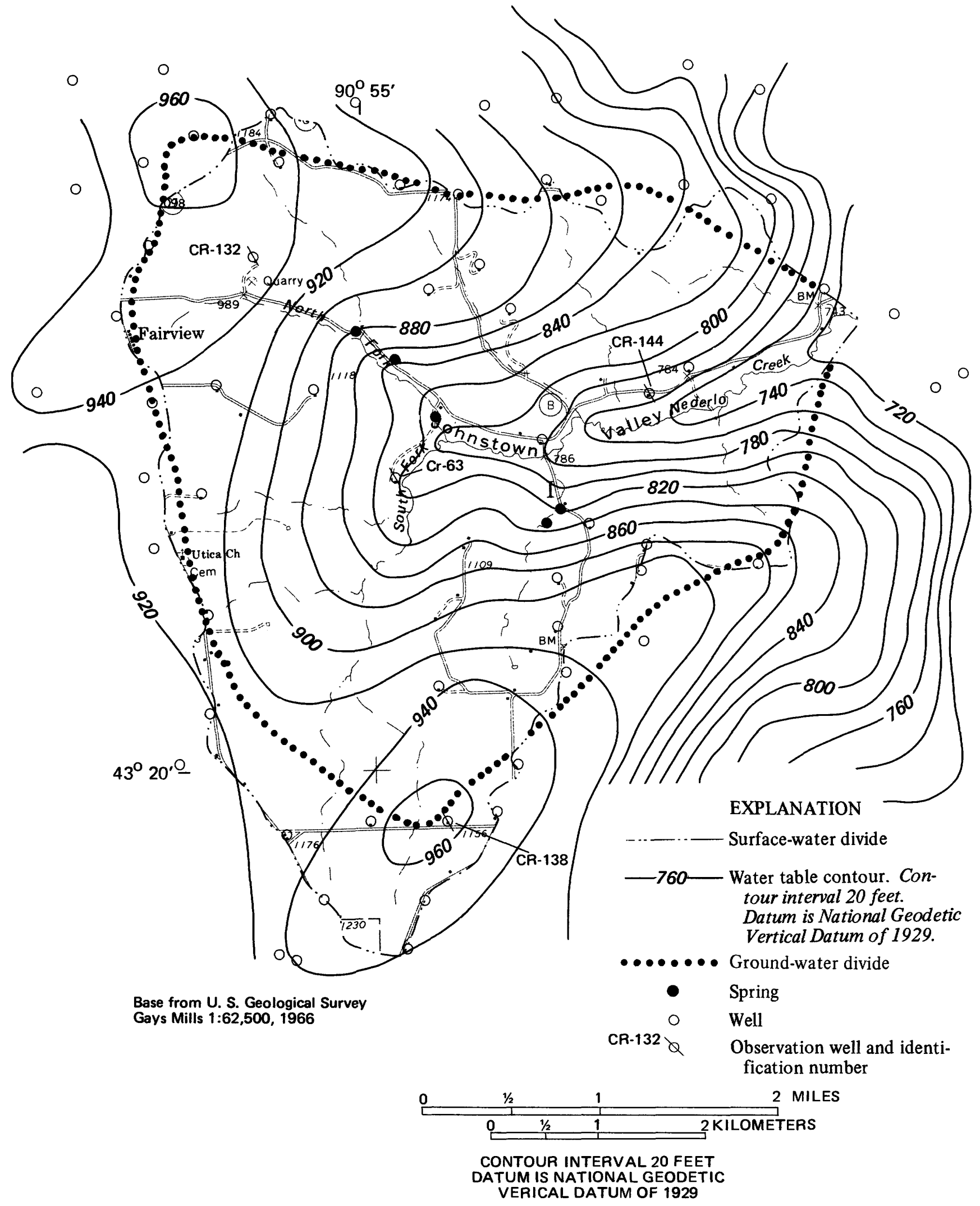

Figure 14. Water table, August and September 1969. 

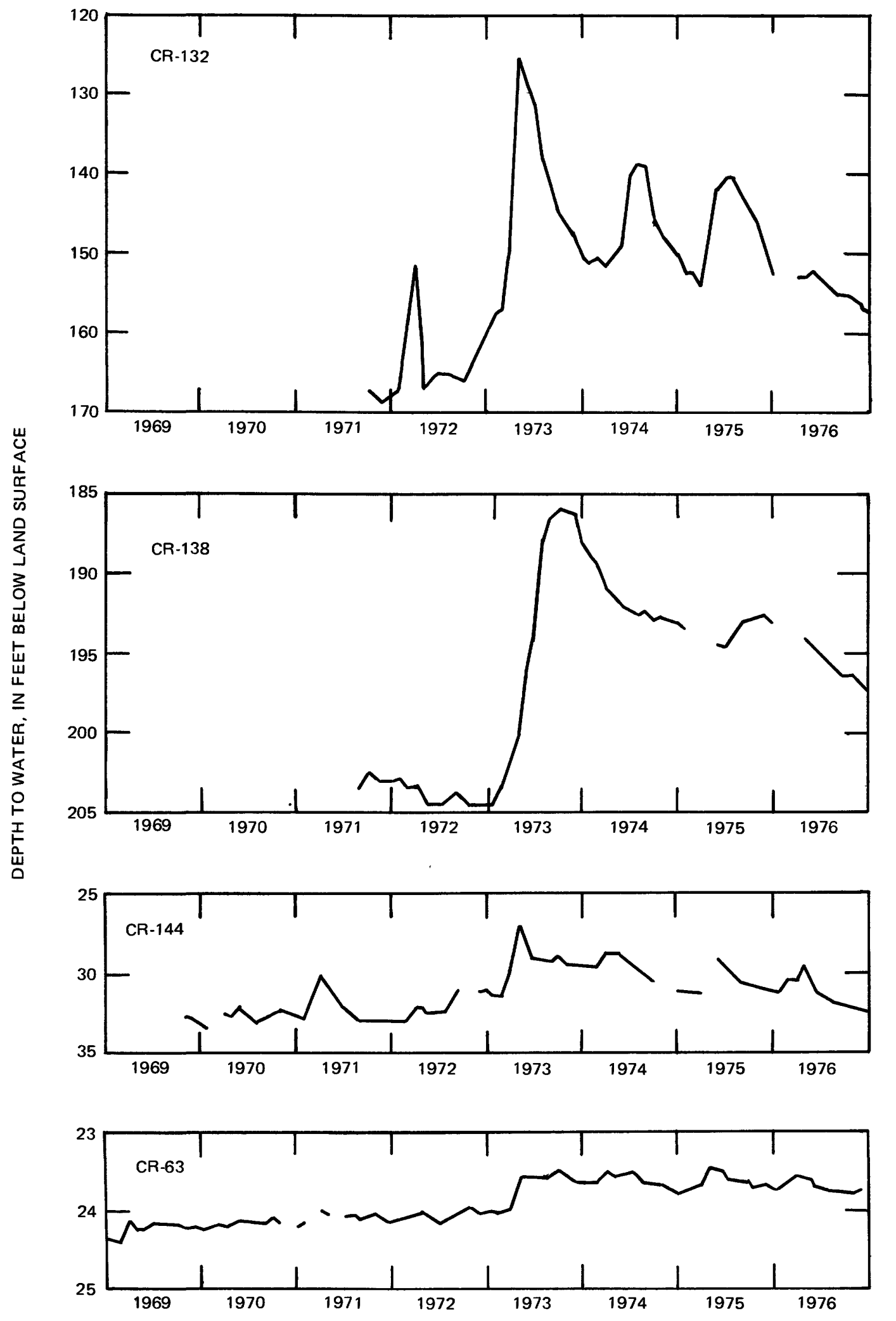

Figure 15. Water level hydrographs for observation wells. 


\section{HYDROLOGIC BUDGET}

Bodies of perched water occur beneath many of the ridges in the area. The log of the public supply well at Mount Sterling, near the south tip of the basin, shows a body of perched water in the Prairie du Chien Group about $120 \mathrm{ft}$ below land surface and about $140 \mathrm{ft}$ above the general water table. Young and Borman (1973, sheet 2) report that perched water commonly occurs in the Galena-Platteville unit (Galena Dolomite, Decorah and Platteville Formations) and the Prairie du Chien Group in this area. The perched water bodies occur where downward percolation of recharge is inhibited by horizontal layers of materials with low permeabilities, such as shale or dense dolomite.

Seasonal and longer term fluctuations in groundwater levels have been measured since 1968 . Figure 15 shows hydrographs of four wells; their locations are shown in figure 14. Details of well construction are not available for the wells, but wells $\mathrm{Cr}-63$ and $\mathrm{Cr}-144$ probably terminate in the Franconia Sandstone and wells $\mathrm{Cr}-132$ and $\mathrm{Cr}-138$ probably terminate in the Jordan Sandstone. Three of the wells are probably at least partly open to overlying formations (St. Lawrence Formation in the case of $\mathrm{Cr}-63$ and the Prairie du Chien Group in the case of $\mathrm{Cr}-132$ and $\mathrm{Cr}-138$ ). Water levels in wells $\mathrm{Cr}-63$ and $\mathrm{Cr}-144$ have been monitored continuously since October 1968 and November 1969, respectively, and water levels in $\mathrm{Cr}-132$ and $\mathrm{Cr}-138$ have been measured at approximately monthly intervals since October 1971.

Ground-water-level changes of different wells reflect the effects of recharge by precipitation and infiltration of snowmelt, and subsequent depletion of stored water by ground-water runoff, to different degrees. Water levels in wells $\mathrm{Cr}-63$ and $\mathrm{Cr}-144$ rise fairly rapidly during periods of recharge and decline fairly rapidly when recharge stops; this quick response is due, at least in part, to the relatively small distance between the land surface and the potentiometric surface, and high permeability of the alluvium. The magnitude of water-level changes in wells $\mathrm{Cr}-132$ and $\mathrm{Cr}-138$ has been greater than in the wells in the valley.

The water level in well $\mathrm{Cr}-132$ responds annually to recharge. The pattern of water-level fluctuations is similar to wells in the valley but the response to recharge usually occurs 1 to 2 months after that of wells in the valley. The water level in well $\mathrm{Cr}-138$ generally has not responded noticeably to annual recharge, and the response to a more sustained period of recharge that occurred in March through May 1973 lagged behind wells in the valley by 5 to 6 months. The areal variation in response to recharge observed in ridge-top wells and the difference in response time between ridge-top and valley wells indicates that recharge under the ridge is retarded by layers of low-permeability material.
Important elements of the hydrologic budget include precipitation, runoff, ground-water underflow, evapotranspiration, and storage changes.

Precipitation (P) is monitored at two sites (fig. 9); the average of data from these two sites was used in budget computations.

Runoff (R) was computed from streamflow records and surface-drainage areas of each subbasin. Runoff was divided into surface-water and groundwater runoff components by hydrograph separation. In the basin of station 30, and most of the basin of station 90 , the surface- and ground-water divides generally coincide. In the basin of station 60 , the surface- and ground-water divides do not coincide; the ground-water drainage area of station 60 is 80 percent of the surface drainage area (fig. 14). This difference in drainage areas also affects the drainage area of station 90 because it includes the ground-and surface-water drainage basins of station 60 . Total runoff and ground-water runoff for stations 60 and 90 were adjusted to include the estimated groundwater loss from the southern tip of the basin that is not monitored by the gaging stations.

Ground water leaving the basin as ground-water underflow (U) through the alluvial material in the valley is not recorded at the gaging stations. Estimates of ground-water underflow computed for each subbasin were less than 0.1 in., which is negligible compared to other elements of the budget.

Water in storage (S) includes ground water and moisture in the unsaturated zone. There is no significant surface-water storage in the basin.

Soil moisture in the upper $2.5 \mathrm{ft}$ of soil was measured periodically at five sites (fig. 9) using a neutron-moisture logger from December 1968 to July 1970 . Available data indicate that net changes in soil-moisture storage through the course of a water year were less than 1 in. The quantity of water in storage in the zone between the upper $2.5 \mathrm{ft}$ of soil and the saturated zone at any given time is unknown. The variation in the time of response of water levels in wells to recharge suggests that there could be substantial quantities of water "in transit" through this zone during much of the year.

Changes in ground-water storage were estimated using net changes in ground-water levels for each water year and estimated specific yields for the various aquifers in the basin. Accurate estimation of storage changes is complicated by areal difference in the magnitude of ground-water-level changes, and by differences in specific vields between aquifers. The following changes in ground-water storage were computed for water years 1968-76. The figures represent the maximum change in ground-water storage that is likely to have occurred during the year. 


$\begin{array}{lcc}\text { Water years } & 1968-71 & \pm 0.4 \mathrm{in.} \text { (each year) } \\ \text { Water year } & 1972 & +.8 \mathrm{in} . \\ \text { Water year } & 1973 & +3.5 \mathrm{in} . \\ \text { Water year } & 1974 & -1.6 \mathrm{in} . \\ \text { Water year } & 1975 & \pm .4 \mathrm{in} . \\ \text { Water year } & 1976 & -1.8 \mathrm{in} .\end{array}$

These figures do not include water temporarily stored in the unsaturated zone. Changes in storage in this zone cannot be accounted for directly, but net long-term changes are probably small. Short-term changes in storage in this zone could be substantial and could have considerable influence on short-term hydrologic-budget computations.

The remaining element of the hydrologic budget, evapotranspiration (ET), was not determined directly. The water loss that is not accounted for by the budget elements that are measured directly is attributed to ET. Because of the method of computation, ET values include any uncertainty or omissions associated with the elements of the hydrologic budget that were measured directly.

Using these budget elements, the hydrologic budget is given by the equation:

$$
P-R \cdot E T \pm U \pm \Delta S=0 \text {. }
$$

A mean annual hydrologic budget for water years 1968-72 and annual budgets for water years 1971 and 1972 were computed for the basin of station 90 .
These budgets, along with runoff and mean discharge data for this station and for the drainage basins of the structures (stations 30 and 60), are given in table 3 . Water years 1971 and 1972 were chosen as examples of dry and wet years, respectively, during the period of record.

The mean annual ET for water years $1968-72$ for the basin of station 90 (25.9 in) is close to the "actual" annual ET of 25.0 in. calculated by Young and Borman (1973, sheet 1) for the Viroqua area (15 $\mathrm{mi}$ to the north of the Nederlo Creek basin) for the period 1931-60. The ET value given by Young and Borman was calculated using the empirical water-balance method described by Thornthwaite and Mather (1957).

\section{WATER QUALITY CHEMICAL CHARACTERISTICS}

Water in the basin is a calcium magnesium bicarbonate type that is similar in chemical quality to water in similar environments nearby.

Chemical analyses were made of water from Nederlo Creek and from 14 wells and 4 springs tapping the Jordan Sandstone, St. Lawrence Formation, and Franconia Sandstone aquifers. The locations of the sampling sites are shown in figure 16 . The water in these sources is hard; median hardness of water from wells is $286 \mathrm{mg} / \mathrm{L}$ as calcium carbonate and median dissolved-solids concentration is

Table 3. Hydrologic budget, runoff, and mean daily discharge for the Nederlo Creek basin

(Values, in inches, except where noted)

\begin{tabular}{|c|c|c|c|c|}
\hline & & $\begin{array}{l}1971 \text { water year } \\
\text { (dry year) }\end{array}$ & $\begin{array}{l}1972 \text { water year } \\
\text { (wet year) }\end{array}$ & $\begin{array}{c}\text { Mean, water years } \\
1968-72\end{array}$ \\
\hline $\begin{array}{l}\text { Hydrologic budget: } \\
\text { Nederlo Creek basin } \\
\text { at station } 90 ; \\
\text { Drainage area } 9.6 \mathrm{mi}^{2}\end{array}$ & $\begin{array}{l}\text { Precipitation }(P) \\
\text { Evapotranspiration }(E T) \\
\text { Runoff }(R) 1 \\
\text { Surface runoff } \\
\text { Ground-water runoff } \\
\text { Change in ground-water } \\
\text { storage }(\triangle S) \\
\text { Underflow }(U)\end{array}$ & $\begin{array}{r}27.5 \\
21.0 \\
6.5 \\
.2 \\
6.3 \\
0 \\
0\end{array}$ & $\begin{array}{r}34.1 \\
26.0 \\
7.3 \\
1.5 \\
5.8 \\
.8 \\
0\end{array}$ & $\begin{array}{r}32.5 \\
25.9 \\
6.4 \\
.7 \\
5.7 \\
.2 \\
0\end{array}$ \\
\hline $\begin{array}{l}\text { Runoff in subbasins: } \\
\text { South fork Nederlo } \\
\text { Creek at station } 60 ; \\
\text { Drainage area } 4.1 \mathrm{mi}^{2}\end{array}$ & $\begin{array}{l}\text { Runoff } 1 \\
\text { Surface runoff } \\
\text { Ground-water runoff }\end{array}$ & $\begin{array}{r}4.7 \\
.1 \\
4.6\end{array}$ & $\begin{array}{l}5.6 \\
1.3 \\
4.3\end{array}$ & $\begin{array}{r}4.9 \\
.7 \\
4.2\end{array}$ \\
\hline $\begin{array}{l}\text { North Fork Nederlo } \\
\text { Creek at station } 30 ; \\
\text { Drainage area } 2.3 \mathrm{mi}^{2}\end{array}$ & $\begin{array}{l}\text { Runoff } \\
\text { Surface runoff } \\
\text { Ground-water runoff }\end{array}$ & $\begin{array}{r}4.1 \\
.1 \\
4.0\end{array}$ & $\begin{array}{l}5.3 \\
1.2 \\
4.1\end{array}$ & $\begin{array}{r}4.5 \\
.6 \\
3.9\end{array}$ \\
\hline $\begin{array}{l}\text { Mean daily discharge } \\
\left(\mathrm{ft}^{3} / \mathrm{s}\right)\end{array}$ & $\begin{array}{l}\text { Station } 90 \\
\text { Station } 60 \\
\text { Station } 30\end{array}$ & $\begin{array}{l}4.3 \\
1.1 \\
.70\end{array}$ & $\begin{array}{l}4.9 \\
1.4 \\
.89\end{array}$ & $\begin{array}{l}4.3 \\
1.2 \\
.76\end{array}$ \\
\hline
\end{tabular}

1 Runoff values adjusted to include estimated ground-water runoff from the southern tip of the basin that is not measured at station 60 . 

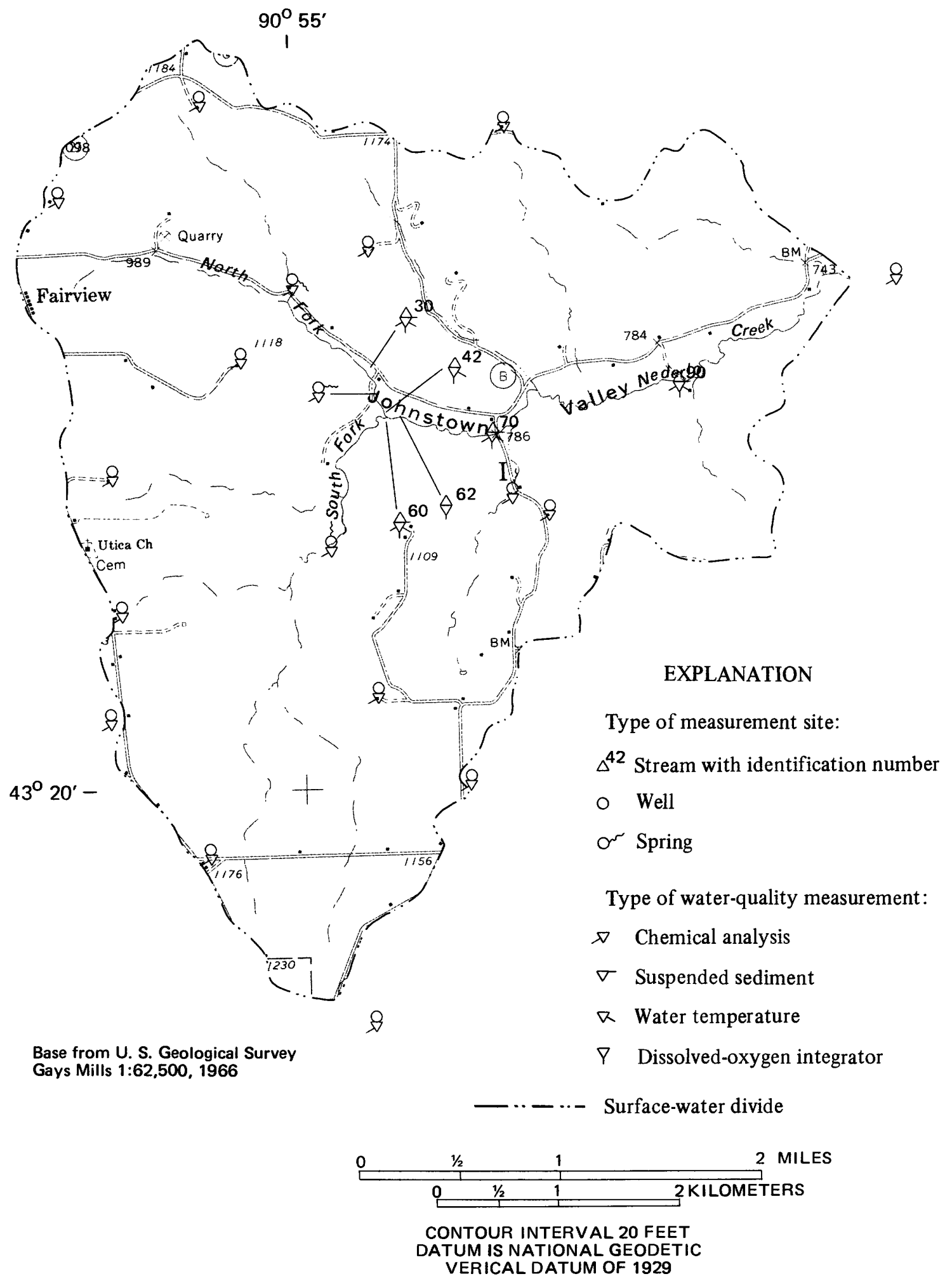

Figure 16. Location of water quality measurement sites. 


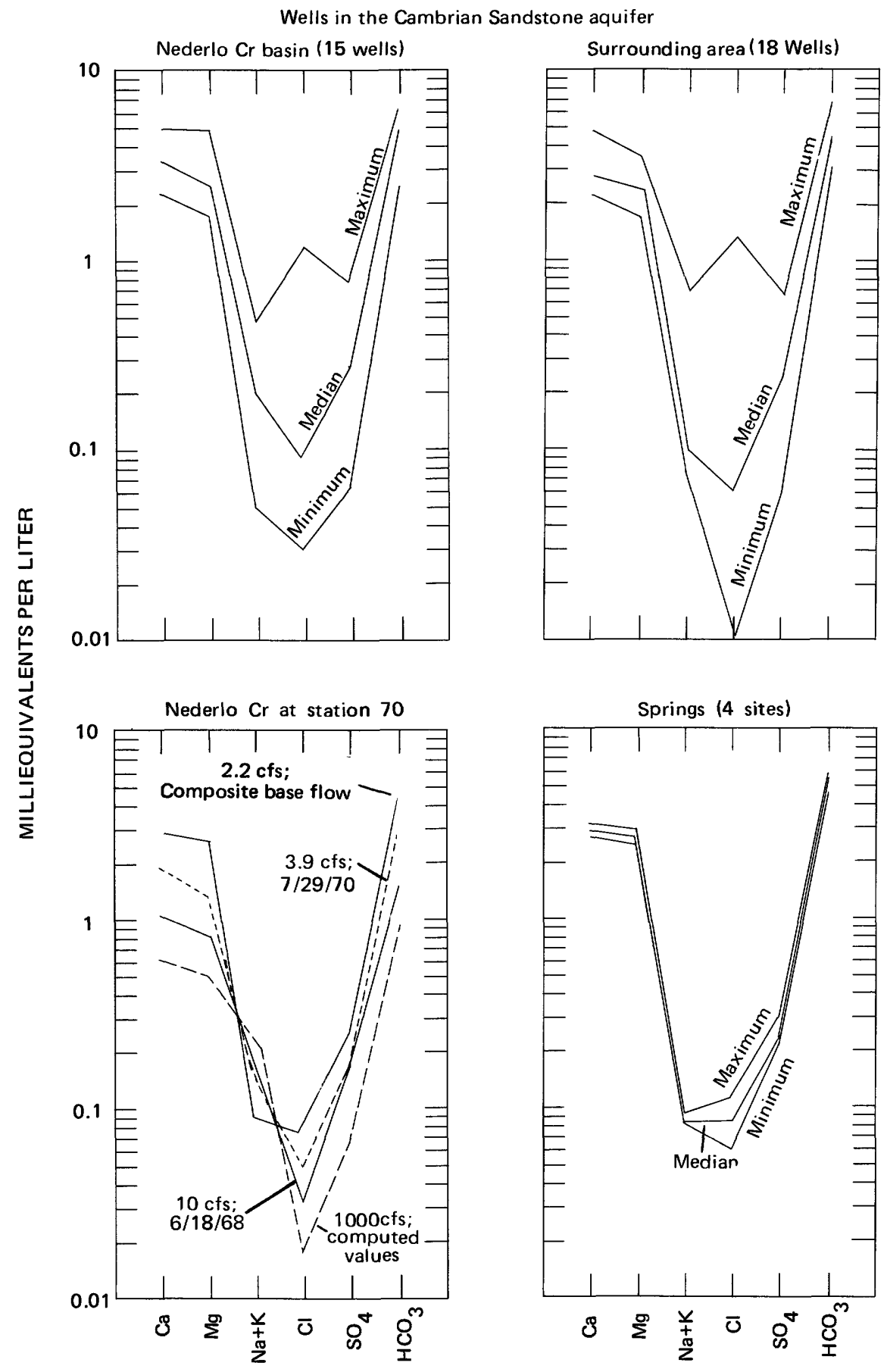

Figure 17. Concentration ranges of major constituents in water. 
$274 \mathrm{mg} / \mathrm{L}$. The range and median concentrations of major ionic constituents in Nederlo Creek, in wells and springs in the basin, and in wells within a radius of approximately $30 \mathrm{mi}$ that tap the same geologic units are shown in the diagrams in figure 17. The constituents shown are calcium, magnesium, sodium plus potassium, chloride, sulfate, and bicarbonate.

Changes in concentrations of major constituents in Nederlo Creek at station 70 with changing discharge are illustrated in figure 17 . The behavior of these constituents at the other three surface-water sampling sites shown in figure 16 (stations 30, 60, and 90) is similar to that observed at station 70 . The base-flow composition represents the mean of 11 samples collected between November 1967 and January 1969 at discharges ranging from 1.8 to $2.7 \mathrm{ft}^{3} / \mathrm{s}$. The mean of these discharges is $2.2 \mathrm{ft}^{3} / \mathrm{s}$, a value equaled or exceeded 60 percent of the time during water years 1968-75. The other three compositions shown represent periods when overland flow was entering the stream directly. Samples collected July 29, 1970, (discharge $3.9 \mathrm{ft}^{3} / \mathrm{s}$ ), and June 18, 1968 (discharge $\left.10 \mathrm{ft}^{3} / \mathrm{s}\right)$, represent discharges that have been equaled or exceeded 6 and 1 percent of the time, respectively. The chemical composition of the stream at a discharge of $1,000 \mathrm{ft}^{3} / \mathrm{s}$ was estimated using records of specific conductance at high discharges and relationships between specific conductance and concentrations of major ionic constituents.

Concentrations of all major constituents at station 70 tend to decrease with increasing discharge except for "sodium plus potassium", which tends to increase with increasing discharge. The increase in the sum of the concentration of these two constituents is due to increasing potassium concentrations; sodium shows the dilution effect exhibited by the other constituents.

The increase in potassium concentration with increasing discharge parallels increases in nitrogen and phosphorus concentration which will be discussed later.

The relationships between concentrations of major constituents in water from springs and from the stream at base flow are similar to each other and similar to that for the median composition of water from wells (fig. 17).

The diagrams in figure 17 for well water show that the relationships between concentrations of various constituents of ground water in the Nederlo Creek basin are similar to those for the surrounding area. Minimum, median, and maximum concentrations show the same general pattern, except for chloride.

Water from several wells has chloride concentrations that are higher in proportion to other constituents than would be expected from consideration of relationships for minimum and median concentrations. The wells with unusually high chloride water are scattered, and no single cause for the high values is apparent. These wells are noticeable mainly because of their contrast to other more "typical" wells in the area; water from "typical" wells has chloride concentrations fairly close to the median values of $3.2 \mathrm{mg} / \mathrm{L}$ for the Nederlo Creek basin and $2.1 \mathrm{mg} / \mathrm{L}$ for the surrounding area. The highest chloride concentration observed in the area is $46 \mathrm{mg} / \mathrm{L}$.

In the area surrounding the Nederlo Creek basin, high chloride concentrations are not associated with correspondingly high values for any other individual chemical constituents, but in the Nederlo Creek basin, water from wells with chloride concentrations greater than about $2 \mathrm{mg} / \mathrm{L}$ above the median value also has nitrate concentrations that are substantially greater than the median nitrate concentration.

Like chloride, nitrate concentration in water from wells in the sandstone aquifer varies more from well to well than other major constituents. Isolated wells in the Cambrian sandstone aquifer in the area surrounding the Nederlo Creek basin having water with nitrate concentrations of 12 to $31 \mathrm{mg} / \mathrm{L}$ nitrate were located by Young and Borman (1973), and analyses of samples collected from wells in the Nederlo Creek basin revealed additional wells with high nitrate. In fact, 4 of 14 wells sampled in the Nederlo Creek basin had nitrate concentrations exceeding the recommended maximum nitrate concentration for drinking water of $44 \mathrm{mg} / \mathrm{L}$ nitrate (U.S. Environmental Protection Agency, 1975, p. 59570). Figure 18 shows the distribution of nitrate concentrations in water from wells in the Nederlo Creek basin and in the Cambrian sandstone aquifer within an approximately $30-\mathrm{mi}$ radius of the basin. Nitrate concentrations observed in the Nederlo Creek basin are generally higher than the concentrations observed in the same aquifer in the surrounding area.

Wells for water-quality sampling in the Nederlo Creek basin were chosen mainly on the basis of their geographic location to show areal variation of water quality. The wells are all older, private farm wells, and, as mentioned earlier, little is known about their physical condition or construction. In contrast, the wells in the adjoining area for which water-quality data were available are public and institutional water supplies or private supplies for which adequate construction information was available. This unavoidable bias in the selection of wells could account for the differences in nitrate concentrations between the two areas. It is reasonable to believe that older, private farm wells would be more susceptible to contamination through leaky seals and casings that could give rise to isolated instances of high nitrate than the newer, better constructed wells in adjoining areas.

\section{DISSOLVED OXYGEN}

Dissolved-oxygen (DO) concentrations in Nederlo Creek and its tributaries have been measured since 1968, using a variety of methods; these include periodic measurements, 24-hour DO surveys, and DO integrating devices. Periodic measurements of DO 


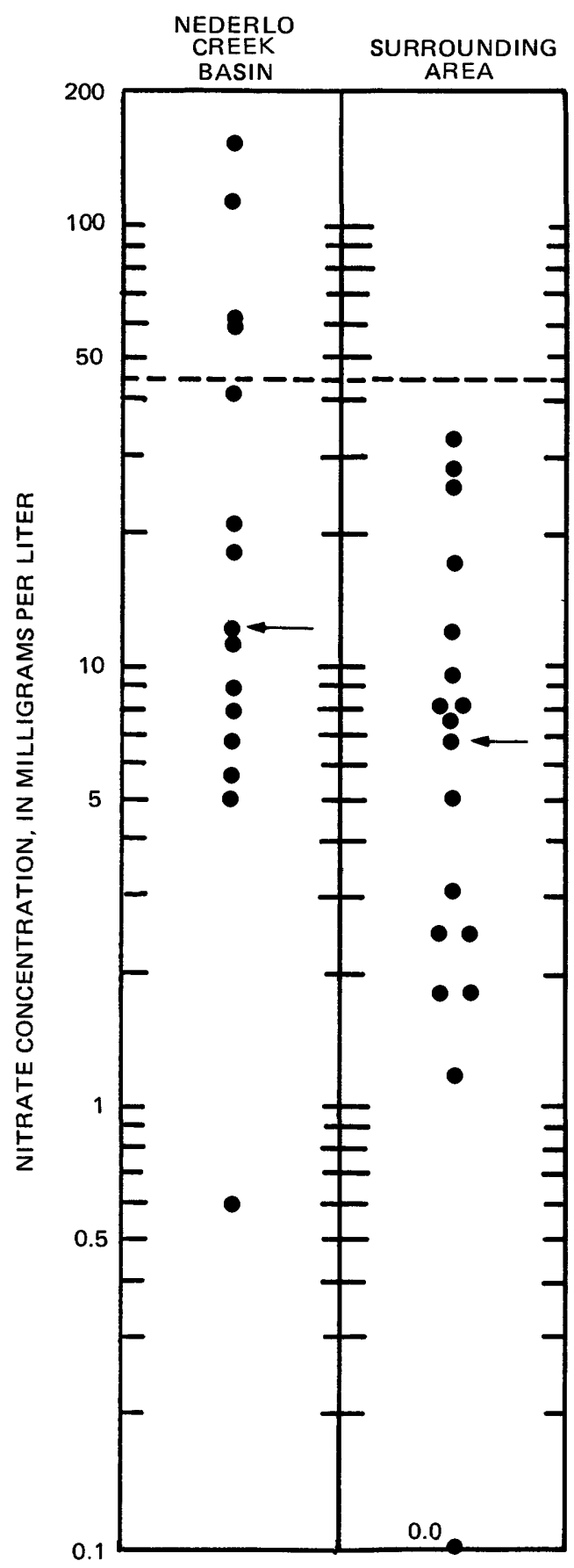

EXPLANATION

- Nitrate concentration

$\longleftarrow$ Median nitrate concentration

- - Maximum recommended nitrate concentration for drinking water (Committee on Water Quality Criteria, 1974)

Figure 18. Nitrate concentrations in the Cambrian sandstone aquifer. 
concentration have been made throughout the year at the four streamflow-monitoring stations (fig. 9) since the beginning of the 1968 water year. These measurements were generally made during daylight hours. Because of this, they reflect the higher daytime concentrations caused by photosynthesis. Daily fluctuations in DO, as well as nighttime minimum concentrations, were measured during periodic 24-hour DO surveys that were conducted in the months of April through November 1968-73.

Dissolved-oxygen integrating devices similar to those described by Slack (1971) were used to measure long-term mean DO concentrations at several sites. The devices consisted of polyethylene bottles filled with water and placed in the stream for approximately 4-week periods.

Mean DO concentrations were monitored using DO integrators from May 1972 through December 1973 at stations 90,70 , and 62 on the main stem, at stations 42 and 30 on the north fork, and at station 60 on the south fork (fig. 9). Integrators were generally placed in the stream for 4 to 5 weeks; at the end of the period, the DO concentration in the intergrator was measured using a DO meter. The measured DO value reflects the mean DO concentration in the stream during the 1 to 2 weeks before the measurement.

The values for each station are plotted on the measurement dates and connected by straight lines in figure 19. The highest "mean" DO concentrations generally occur in November through April and the lowest values during July and August. An interesting exception to this seasonal trend is seen at station 42, where most of the measurements fall between 9.5 and $11.5 \mathrm{mg} / \mathrm{L}$. Approximately onethird of the streamflow at this station at base flow is derived from a spring (station 40 ) about 200 yards upstream, which has a DO concentration between 9 and $10 \mathrm{mg} / \mathrm{L}$ throughout the year. This input of water with a relatively constant DO concentration and temperature probably moderates DO fluctuations at station 42 .

Sufficient 24-hour DO data and miscellaneous DO measurements were available for stations 70 and 90 on the main stem of Nederlo Creek to permit construction of generalized curves showing probable seasonal fluctuations in maximum and minimum daily DO concentrations for all but the winter months. These curves are plotted in figure 19. The
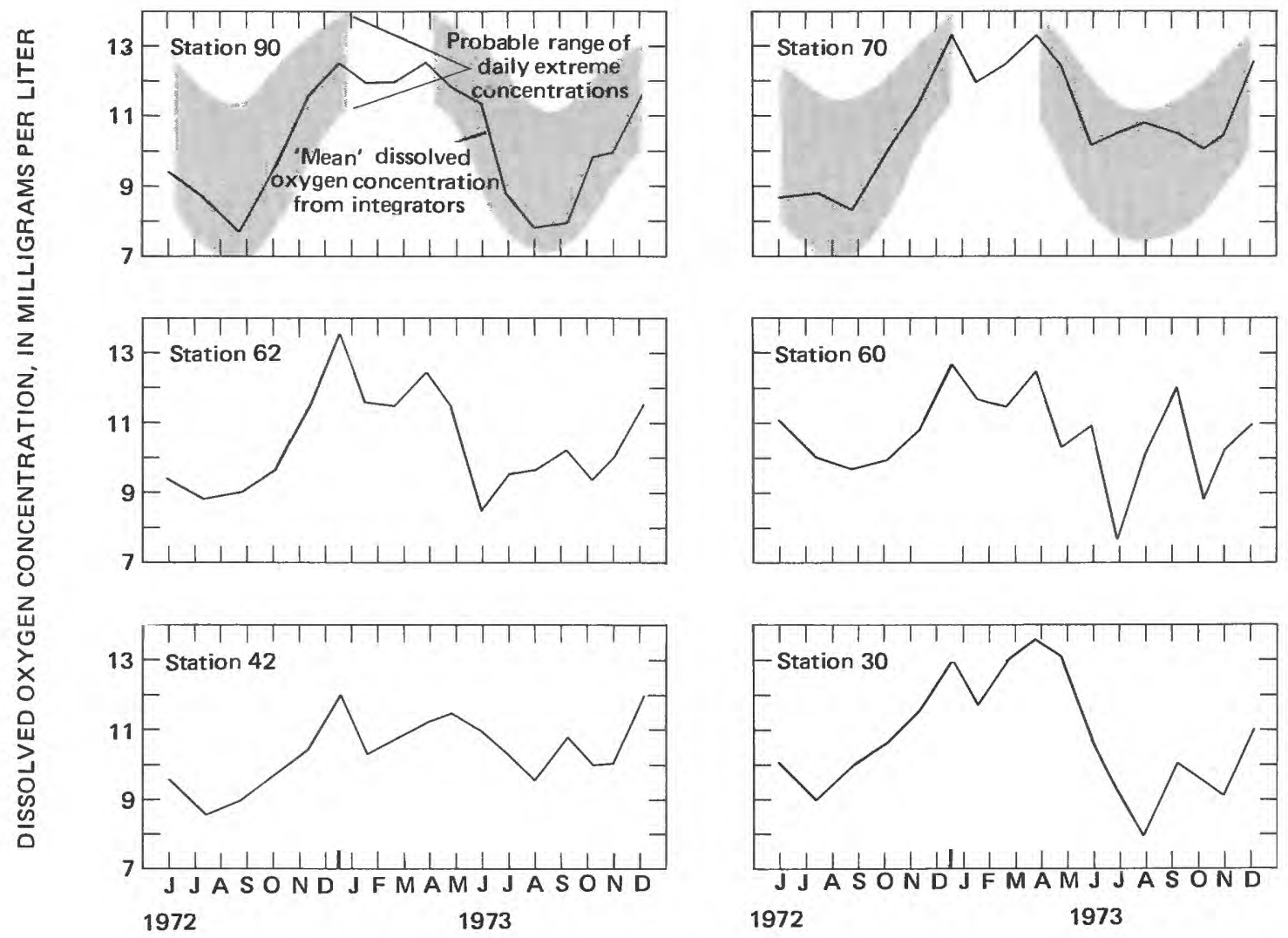

Figure 19. Mean and generalized range of daily extreme dissolved oxygen concentrations in Nederlo Creek. 
lowest maximum and minimum DO and the greatest range between minimum and maximum occur during the summer months. The summer minimum values at both stations are generally between 7 and $8 \mathrm{mg} / \mathrm{L}$, and the summer maximums are generally between 11 and $12.5 \mathrm{mg} / \mathrm{L}$. Midwinter extremes of DO at the stations have not been measured by 24-hour DO surveys, but DO integrator data and extrapolation of extremes measured in late fall and early spring indicate that winter DO is generally between 11 and $14 \mathrm{mg} / \mathrm{L}$.

\section{WATER TEMPERATURE}

Water temperatures were monitored continuously at several sites (fig. 9). The longest and most complete record is for station 70 where water temperature has been recorded since the 1968 water year. Temperature recorders also were operated at stations 30,60 , and 90 during May through September 1970, and continuously since May 1974 at stations 42 and 60 .

The major factors influencing daily and seasonal water-temperature fluctuations are the temperature of ground water entering the stream and subsequent heat exchange between water in the stream and the environment.

During base-flow periods, streamflow consists of ground-water runoff derived from springs in bedrock aquifers and seepage along the stream channel. The temperature of ground water from springs is relatively constant throughout the year, generally $8^{\circ}$ to $10^{\circ} \mathrm{C}$. The temperature of water entering the stream from alluvium was not measured, but seasonal temperature variations probably occur. Pluhowski (1972, p. C261) reported a July water temperature of $16.7^{\circ} \mathrm{C}$ for ground water beneath a stream similar to Nederlo Creek, indicating that the temperature of near-surface ground water may be influenced considerably by seasonal changes in ambient temperature. Environmental influences on the temperature of surface water at base flow include heating by solar radiation and reversible heat exchange with the stream channel and with the atmosphere.

The general range of daily temperature fluctuation varies seasonally and from site to site. The daily range of temperature at all stations is greater during summer than winter, and station to station differences in the range of daily temperature fluctuation are greater in the summer.

In summer, the range of daily temperature fluctuation and daily extremes are influenced by the distance between the temperature measurement site and springs in bedrock aquifers. Streamflow at stations 30 and 42 is comprised largely of discharge from nearby springs (fig. 13); maximum and minimum daily water temperatures during summer are generally lower, and daily temperature range smaller, than those observed at stations 60, 70, and 90 . Stations 70 and 90 are situated approximately 3 and 7 hours of traveltime, respectively, downstream from springs with sufficient discharge relative to streamflow to affect downstream temperature characteristics. Streamflow at station 60 is approximately equal to that at station 42 and the distance between the stations and their respective headwaters are similar, but influence of spring discharge at station 60 is less than at station 42 (fig. 13). Because of this, summer temperature characteristics at station 60 resemble those at stations 70 and 90 more than those at stations 30 or 42 .

Temperature recorders were operated concurrently at stations 30, 60, 70, and 90 in May-September of 1970. A frequency analysis of daily maximum and minimum water temperatures recorded during this period illustrates the relative summer temperature characteristics at these stations. Frequency curves in figure 20A show that higher daily maximum and minimum temperatures occur, and that higher temperatures occur more frequently at stations less subject to the influence of major springs.

Water temperatures generally were higher during May-September of 1970 than for the composite of identical periods for the years 1968-76. This is illustrated by comparison of the frequency curves for the period 1968-76 with the curves for 1970 (fig. 20B) for temperatures at station 70 .

Frequency curves for stations 42 and 60 (fig. 20C) for the 3-year period 1974-76 (May through September) show the difference in temperature characteristics caused by the source of, and distance to, ground-water input at base flow. As stated previously, the streams passing these monitoring stations are similar in many respects but differ with respect to ground-water input at base flow. Approximately 85 percent of the base flow at station 42 is from springs and about one-third of the base flow is derived from a major spring 200 yards upstream. In contrast, only 33 percent of the base flow at station 60 is from springs, none of which are located near the monitoring station.

The springs upstream from station 42 moderate summer water temperatures with respect to both diurnal fluctuation and the range and magnitude of extreme values. The frequency curves in figure $20 \mathrm{C}$ show that the range of maximum daily water temperatures measured at station 42 is considerably less than at station 60 and that high temperatures occur less frequently at station 42 . Minimum daily water temperatures at station 42 also fall within a narrower range of values than those at station 60 . Minimum daily water temperatures were between $7^{\circ}$ and $13^{\circ} \mathrm{C}$ at station 42 and between $6^{\circ}$ and $15^{\circ} \mathrm{C}$ at station 60,98 percent of the time during the period of comparison.

Maximum daily water temperatures during summer are often in the range of the upper tolerance limits of $18^{\circ}$ to $24^{\circ} \mathrm{C}$ for trout reported in a review by Novitzki (1973, p. 4). Although temperatures within and exceeding this range are fairly common at most of the monitoring stations (fig. 20); they 


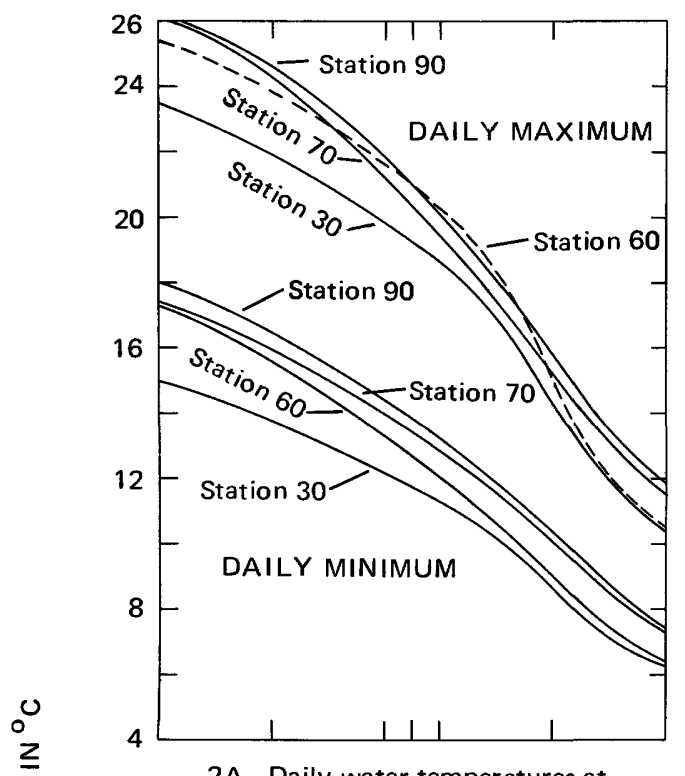

2A. Daily water temperatures at stations 30,60, 70, and 90, 1970.

2C. Comparison of daily temperature characteristics at stations 42 and 60 .

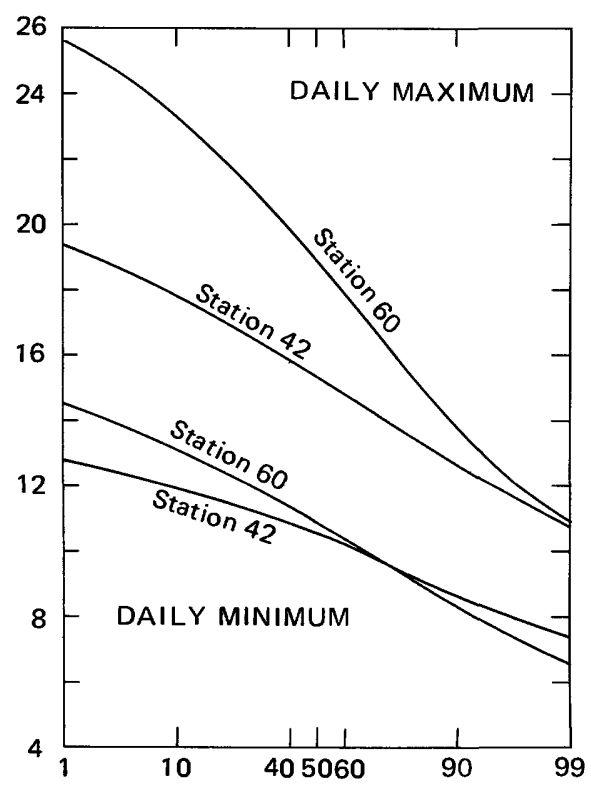

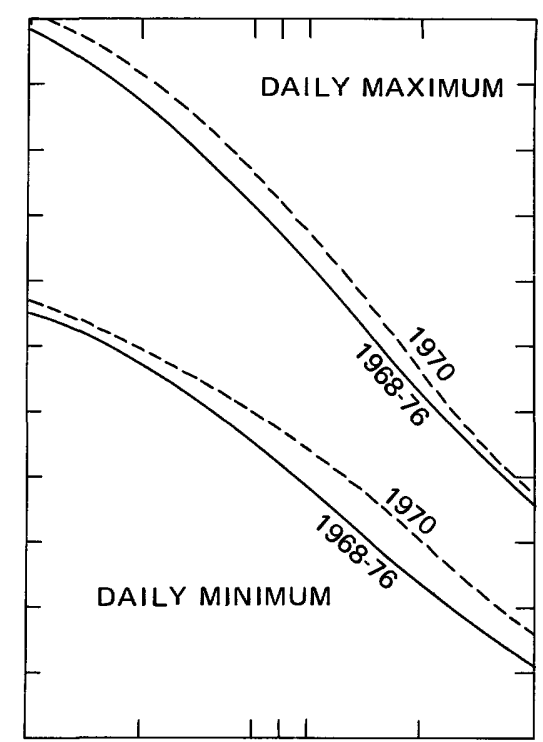

2B. Comparison of daily water temperatures for 1970 and 1968-76 at station 70 .

2D. Duration of daily maximum water temperature at station $70,1968-71$.

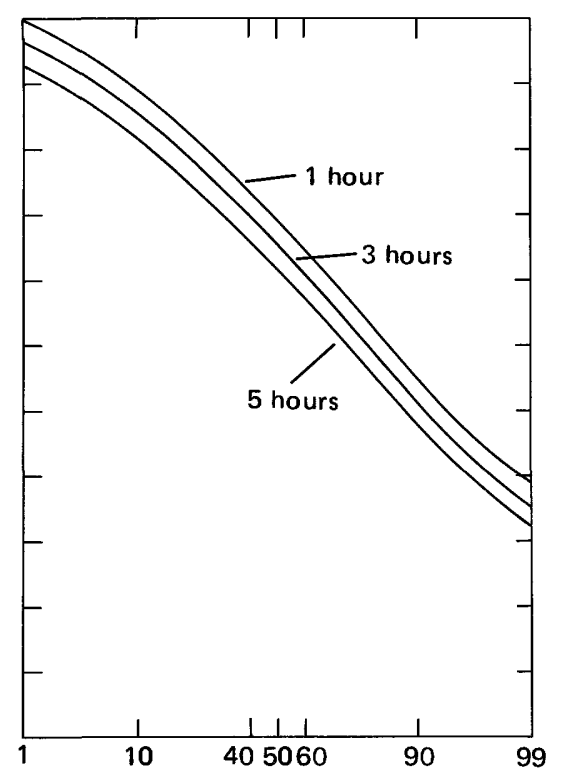

PERCENT OF DAYS IN MAY THROUGH SEPTEMBER THAT THE INDICATED MAXIMUM OR MINIMUM WATER TEMPERATURE WAS EQUALED OR EXCEEDED

Figure 20. Frequency relationships for summer water temperatures in Nederlo Creek. 
seldom persist for long periods. A frequency analysis of the duration of maximum daily water temperatures at station 70 during May through September of 1968-71 was prepared for temperature durations of 1,3 , and 5 hours (fig. 20D). The 1-hour duration curve is essentially a daily frequency curve for the period 1968-71 corresponding to those for other periods shown in figure $20 \mathrm{~B}$. The 3 - and 5 -hour duration curves show the relative "persistence" of the maximum daily water temperature. A temperature equal to or exceeding $24^{\circ} \mathrm{C}$, for example, is likely to occur on 10 percent of the days, but a temperature equal to or exceeding $24^{\circ} \mathrm{C}$ is likely to persist for 5 or more consecutive hours on only 2 percent of the days.

Water temperatures for December-February are influenced less by differences in gound-water input upstream from monitoring stations than are summer water temperatures. Maximum daily water temperatures at stations for which winter records are available (stations 42,60 , and 70 ) seldom exceed $7^{\circ}$ or $8^{\circ} \mathrm{C}$ and are usually less than $5^{\circ} \mathrm{C}$ during these months. Ground-water input upstream from station 42 increases minimum daily water temperatures at this station during winter months. This effect is particularly noticable during periods of extreme cold; during these periods water temperatures at stations 60 and 70 may stay at $0^{\circ} \mathrm{C}$ for several consecutive days, while the temperature at station 42 generally rises above $0^{\circ} \mathrm{C}$ during each diurnal cycle.

\section{TRANSPORT OF DISSOLVED AND SUSPENDED MATERIAL}

Overland flow causes increases in the concentration, as well as the load, of nitrogen, phosphorus, and sediment in the stream, and decreases in concentrations of common mineral constituents. This is due to the different sources of the two classes of materials; common mineral constituents discussed under "Water Quality" are derived mainly from solution of soil and rock by ground water, whereas nitrogen, phosphorus, and sediment are derived primarily from the land surface.

Total nitrogen, total phosphorus, and suspendedsediment loads were all computed using the same general procedure. Good correlations were found between load and discharge for data collected during periods when surface runoff contributed to streamflow, but correlations for data collected at base flow were poor. Because of this, loads for base flow periods and periods when surface runoff contributed to streamflow were computed separately and combined to obtain the total load.

For periods when surface runoff contributed to streamflow, a generalized relationship between discharge and load was developed for each sampling station from individual analyses using a computerized curve-fitting procedure. The relationship, a straight line fitted to a log plot of instantaneous discharge versus instantaneous load, was expressed as a first order equation. Flow-duration data and instantaneous loads computed using the equation were used to compute time-weighted mean annual loads.

Mean annual loads transported during base-flow periods were calculated from the arithmetic mean of instantaneous loads during these periods.

Computed total nitrogen and total phosphorus loads are based on periodic samples collected over a wide range of discharges at stations $30,60,70$, and 90 between 1967 and 1974 . The samples, collected by U.S. Geological Survey personnel and employees of the DNR were analyzed by DNR laboratories. Analyses included total phosphorus (organic and inorganic phosphorus species) and total nitrogen (ammonia, nitrate, nitrite, and organic nitrogen). Because analyses were run on "whole water" samples, analytical results include both dissolved and particulate material.

The relationships between load and stream discharge varied considerably with season of the year, intensity and nature of precipitation, and streamflow characteristics. The number of samples collected was insufficient to completely define total nitrogen and phosphorus loads over the full range of conditions occurring during the period, but the range of computed mean annual load values for the four stations indicates the magnitude of nitrogen and phosphorus loads transported in the basin, as well as the importance of surface runoff in the transport.

The mean of average annual total phosphorus and total nitrogen loads for the four stations fell within the ranges of 0.02 to 0.07 and 0.4 to 0.8 tons $/ \mathrm{mi}^{2}$, respectively; approximately 70 to 80 percent of the total phosphorus and 35 to 55 percent of the total nitrogen were transported during periods when surface runoff contributed to streamflow. Stations with the largest surface drainage areas generally had the highest total nitrogen and phosphorus yield per square mile.

The quantity and particle-size distribution of suspended sediment transported by a stream are determined by rainfall intensity and duration, temperature, soil character, topography, and soil cover (Guy, 1970, p. 11). The method used to compute suspended-sediment loads integrates the effects of these factors by using data that represent the entire range of conditions in the basin.

Mean annual suspended-sediment loads for the period $1968-74$ at stations $30,60,70$, and 90 were $13,20,37$, and 60 tons $/ \mathrm{mi}^{2}$, respectively. As in the case of total nitrogen and total phosphorus loads, much of the suspended-sediment load is transported during periods of surface runoff. Eighty-three to 86 percent of the suspended load at stations 60,70 , and 90 , and 74 percent at station 30 , is transported during the 10 percent of the time that overland flow contributes to streamflow. 
These suspended-sediment loads are at the low end of the range previously reported for streams in the "Driftless Area" (34 to 680 tons $/ \mathrm{mi}^{2}$ ) and considerably below the median yield of 200 tons $/ \mathrm{mi}^{2}$ reported for the area (Hindall, 1975, p. 8). This may be because only one flood of sufficient magnitude to cause the stream to overflow its banks has occurred during the period under consideration, and no sed-iment concentration data were obtained. Concentration data from extreme floods would result in higher loads than those presently determined.

Bed-material transport was not measured, but probably amounts to 5 to 15 percent of the suspended load (Hindall, 1975, p. 4-7).

The particle-size distribution of suspended sediment transported by the stream varies considerably when surface runoff contributes to streamflow. This variation is illustrated by the differences in the particle-size distribution of suspended sediment transported during two runoff events that occurred in March-April of 1972 and 1969 but differed in magnitude and cause (fig. 21).
Overland flow from $1.10 \mathrm{in}$. of rain that fell on April 4, 1969, caused relatively small increases in stream discharge at stations $30,60,70$, and 90. Particle-size analyses of samples collected at discharges of 2 to 5 times base flow as the stage was receding show that the suspended sediment was predominantly clay (finer than $0.004 \mathrm{~mm}$ ) with lesser quantities of silt $(0.004$ to $0.062 \mathrm{~mm}$ ) and minor amounts of sand (coarser than $0.062 \mathrm{~mm}$ ).

Runoff from snowmelt that occurred during the period March 14-17, 1972, caused considerably higher discharges ( 30 to 100 times base flow). Particle-size distribution of suspended sediment was fairly uniform during rising and falling stages at all stations, but the sediment was predominantly silt, with approximately equal concentrations of clay and sand. The larger proportion of silt and sand-size particles in the suspended sediment transported in March 1972 was probably due to the higher discharges and water velocities.

Bed-material particle size is dependent on local stream environment. Bed material found in riffles in

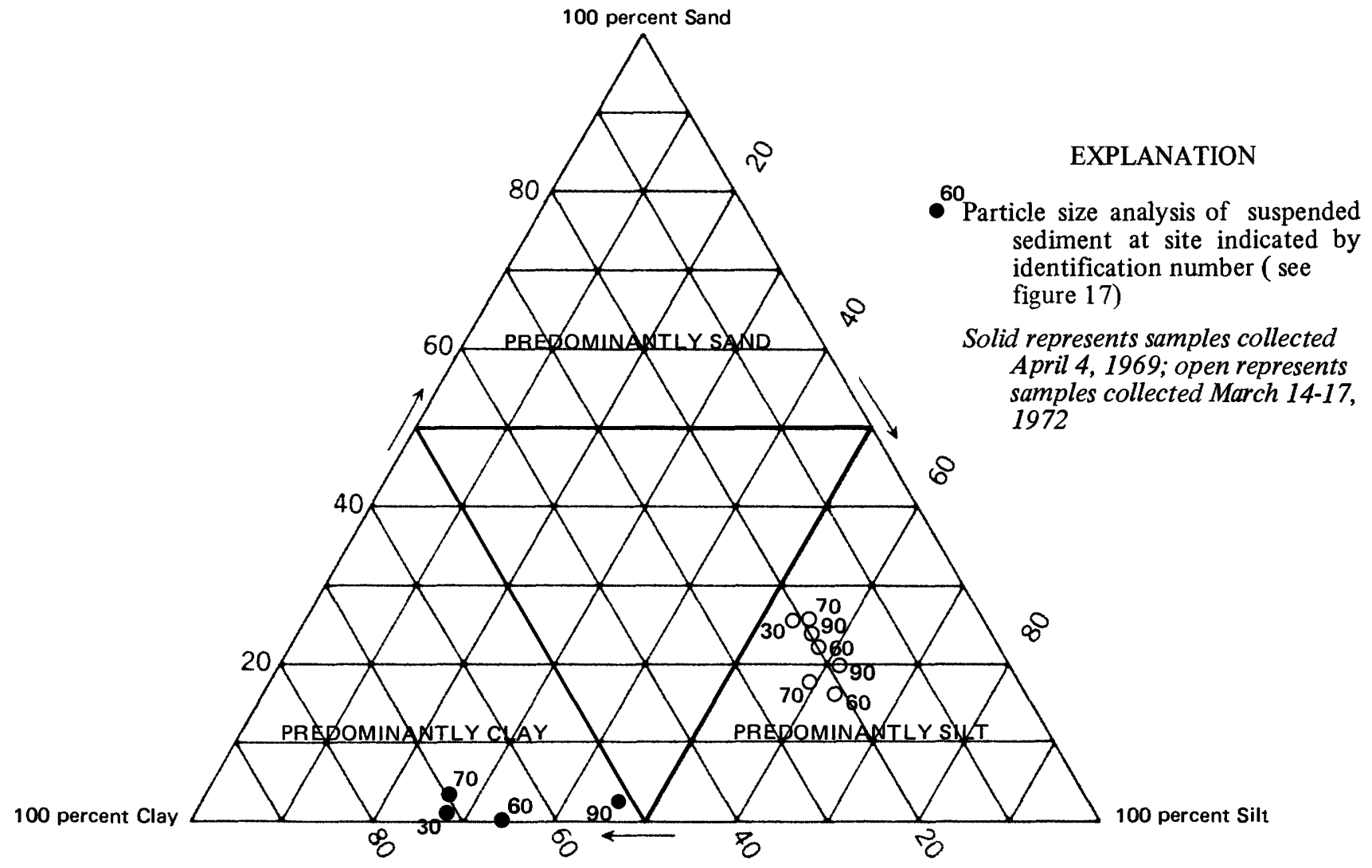

Figure 21. Particle size distribution of suspended sediment. 
perennial reaches of the stream generally ranges from coarse gravel to boulders derived from weathering of bedrock. Bed material in pools is predominantly sand, with lesser quantities of silt and clay. In intermittent streams (dry washes) tributary to perennial streams, bed material is generally sand or coarser.

\section{CONCLUSIONS}

Description of the physical characteristics of a basin and preconstruction hydrology and water quality are necessary prerequisites to an evaluation of the effects of reservoirs and flood-control structures. This preconstruction study of the Nederlo Creek basin provides the foundation for a postconstruction . evaluation of the effects of the dry flood-water control structure and the proposed multipurpose reservoir on the hydrologic system and downstream water quality. Description of the basin's physical setting (geography, geology, soils, and land use) aids in understanding the preconstruction hydrology and water quality and provides a basis for determining the applicability of the results of this study to other basins. The hydrologic monitoring and water-quality measurements conducted during this preconstruction study provide a base of data against which the effects of the structures themselves can be measured.

\section{LITERATURE CITED}

Crawford and Vernon County Soil and Water Conservation Districts, 1967, Watershed work plan, Blackhawk-Kickapoo Watershed: Crawford and Vernon County Soil and Water Conservation Districts, $32 \mathrm{p}$.

Curtis, J. T., 1959, The vegetation of Wisconsin: The University of Wisconsin Press, Madison, $657 p$.

Edwards, M. J., Geib, W. J., Larson, Olaf, Wilcox, D. E., and Tyler, E. H., 1930, Soil survey of Crawford County, Wisconsin: U.S. Department of Agriculture, Bureau of Chemistry and Soils, Series 1930, No. 34, 39 p., 1 map.

Guy, H. P., 1970, Fluvial sediment concepts: U.S. Geological Survey Techniques of Water Resources Investigations, Book 3, Chap. C1, 55 p.

Hindall, S. M., 1975, Measurement and prediction of sediment yield in Wisconsin streams: U.S. Geological Survey Water-Resources Investigations $54-75,33 \mathrm{p}$.
McKee, J. E., and Wolf, H. W., 1963, Water quality criteria: The Resources Agency of California, State Water Quality Control Board Publication No. 3-A, 458 p.

Novitzki, R. P., 1973, Improvement of trout streams in Wisconsin by augmenting low flows with ground water: U.S. Geological Survey Water-Supply Paper 2017, $52 \mathrm{p}$.

Pluhowski, E. J., 1972, Clear-cutting and its effect on the water temperature of a small stream in northern Virginia, in Geological Survey Research, 1972: U.S. Geological Survey Professional Paper 800-C, p. C257-C262.

Slack, K. V., 1971, Average dissolved oxygen measurements and water quality significance: Water Pollution Control Federation Journal, v. 43, no. 3, pt. 1, p. 433-446.

Slota, R. W., and Garvey, G. D., 1961, Soil survey of Crawford County, Wisconsin: U.S. Soil Conservation Service, Soil Survey Series 1958, No. 18, $85 \mathrm{p}$.

Thornthwaite, C. W., and Mather, J. R., 1957, Instructions and tables for computing potential evapotranspiration and the water balance: Centertown, N. J., Drexel Institute of Technology, Climatology Publications, v. 10, no. 3, p. 185-311.

U. S. Environmental Protection Agency, 1975, National interim primary drinking water regulations: Federal Register, v. 40, no. 248, Wednesday, December 24, 1975, pt. IV, p. 59,566-59,587.

U.S. Water Resources Council, 1967, A uniform technique for determining flood flow frequencies: U.S. Water Resources Council Bulletin 15, 15 p.

Wisconsin Conservation Department, 1966, Wisconsin trout streams: Wisconsin Conservation Department Publication 213-66, $75 \mathrm{p}$.

Wisconsin Department of Agriculture, 1961, Wisconsin Climatological Data: Wisconsin Crop Reporting Service Publication, 80 p. (approx.)

Young, H. L., and Borman, R. G., 1973, Water resources of Wisconsin--Trempealeau-Black River basin: U.S. Geological Survey Hydrologic Investigations Atlas HA-474. 